\title{
Applications of Organic and Inorganic Amendments Induce Changes in the Mobility of Mercury and Macro- and Micronutrients of Soils
}

\author{
Mercedes García-Sánchez, Adéla Šípková, Jiřina Száková, Lukáš Kaplan, \\ Pavla Ochecová, and Pavel Tlustoš \\ Department of Agro-Environmental Chemistry and Plant Nutrition, Faculty of Agrobiology, Food and Natural Resources, \\ Czech University of Life Sciences, Suchdol, 16521 Prague 6, Czech Republic \\ Correspondence should be addressed to Jiřina Száková; szakova@af.czu.cz
}

Received 11 June 2014; Revised 3 September 2014; Accepted 24 September 2014; Published 23 October 2014

Academic Editor: Antonio Paz González

Copyright (C) 2014 Mercedes García-Sánchez et al. This is an open access article distributed under the Creative Commons Attribution License, which permits unrestricted use, distribution, and reproduction in any medium, provided the original work is properly cited.

\begin{abstract}
Both soil organic matter and sulfur (S) can reduce or even suppress mercury ( $\mathrm{Hg}$ ) mobility and bioavailability in soil. A batch incubation experiment was conducted with a Chernozem and a Luvisol artificially contaminated by $440 \mathrm{mg} \cdot \mathrm{kg}^{-1} \mathrm{Hg}$ showing wide differences in their physicochemical properties and available nutrients. The individual treatments were (i) digestate from the anaerobic fermentation of biowaste; (ii) fly ash from wood chip combustion; and (iii) ammonium sulfate, and every treatment was added with the same amount of S. The mobile $\mathrm{Hg}$ portion in Chernozem was highly reduced by adding digestate, even after 1 day of incubation, compared to control. Meanwhile, the outcome of these treatments was a decrease of mobile $\mathrm{Hg}$ forms as a function of incubation time whereas the contents of magnesium $(\mathrm{Mg})$, potassium $(\mathrm{K})$, iron $(\mathrm{Fe})$, manganese $(\mathrm{Mn})$, copper $(\mathrm{Cu})$, zinc $(\mathrm{Zn})$, and phosphorus $(\mathrm{P})$ were stimulated by the addition of digestate in both soils. The available calcium $(\mathrm{Ca})$ contents were not affected by the digestate addition. The experiment proved digestate application as the efficient measure for fast reduction of mobile $\mathrm{Hg}$ at extremely contaminated soils. Moreover, the decrease of the mobile mercury portion was followed by improvement of the nutrient status of the soils.
\end{abstract}

\section{Introduction}

Industrial activities have increased the proportion of $\mathrm{Hg}$ in the atmosphere and oceans and have contaminated a number of local environments [1]. From the ecotoxicological point of view, critical limits of $\mathrm{Hg}$ (given as soil element contents above which unacceptable effects are expected) are substantially lower than values derived for other metals such as $\mathrm{Cd}, \mathrm{Cu}, \mathrm{Ni}, \mathrm{Pb}$, and $\mathrm{Zn}$ [2]. Li et al. [3] compared the mobility and plant-availability of risk elements from industrially contaminated soil where the soil-to-plant transfer coefficients were in the order of $\mathrm{Cd}>\mathrm{Zn}>\mathrm{Cu}>\mathrm{Hg}>\mathrm{As}>\mathrm{Pb}$, confirming the relatively low availability of soil $\mathrm{Hg}$ for various vegetables. Rodrigues et al. [4] observed the water-soluble contents of $\mathrm{Hg}$ in highly contaminated sediment and soil samples (total $\mathrm{Hg}$ contents even higher than $3000 \mathrm{mg} \cdot \mathrm{kg}^{-1}$ ) to be less than $1.2 \%$ of the total $\mathrm{Hg}$ content. Boszke et al. [5] classified the divalent and elemental $\mathrm{Hg}$ bounds to humic matter/organic matter as the "semimobile" element portion and observed low portions of the water-soluble Hg species as well.

Luo et al. [6] suggested that soil organic matter and nitrogen were the important sinks for $\mathrm{Hg}$ in the soils. The good capacity of $\mathrm{Hg}$ for adsorption and complexation in the solid media resulted in limited bioaccessibility of this element, which was reported by Hassen et al. [7]. Distribution coefficients for $\mathrm{Hg}^{2+}$ binding by humic acids were determined by Khwaja et al. [8], confirming that the calculated concentration of free $\mathrm{Hg}^{2+}$ at equilibrium is very low. Also, Heeraman et al. [9] observed decreasing Hg mobility and plant-availability in the organic matter-treated soil. The importance of soil organic matter for $\mathrm{Hg}$ mobility and bioavailability in soil samples is known and well described $[5,10]$. As observed by Yao et al. [11], the addition of humus can either suppress or promote $\mathrm{Hg}$ bioavailability depending on the soil composition. In 
this context, the effect of a particular humus fraction on $\mathrm{Hg}$ bioavailability is related to its ability to convert $\mathrm{Hg}$ bound by solid phases into soluble complexes, as well as the stability of the released complexes. On the contrary, the presence of dissolved organic matter (DOM) can significantly reduce maximum $\mathrm{Hg}$ adsorption capacity and even promote $\mathrm{Hg}$ desorption from the soils [12].

Zagury et al. [13] evaluated the potential mobility and plant-availability of $\mathrm{Hg}$ in the highly contaminated soils by chlor-alkali plants, where the total $\mathrm{Hg}$ contents in soil reached up to $11500 \mathrm{mg} \cdot \mathrm{kg}^{-1}$. Although the water extractable $\mathrm{Hg}$ portion was relatively low with regard to the high total content, it represented significant concentrations correlating with $\mathrm{Hg}$ uptake by experimental plants.

Reis et al. [14] observed that the presence of $\mathrm{Hg}$ in the mobile phase could be related to $\mathrm{Mn}$ and aluminum (Al) soil contents. A positive relation between $\mathrm{Hg}$ in the semimobile fraction and the $\mathrm{Al}$ content was also observed. On the contrary, organic matter and $\mathrm{S}$ contents contributed to $\mathrm{Hg}$ retention in the soil matrix, reducing the mobility of the metal. Sulfide minerals are known to be effective adsorbents for $\mathrm{Hg}(\mathrm{II})$ being the primary sink for $\mathrm{Hg}$ in the environment [15]. In this context, Hesterberg et al. [16] demonstrated the preferential binding of $\mathrm{Hg}(\mathrm{II})$ to reduced organic $\mathrm{S}$ sites. Subsequently, similar observations were provided and described in soils as mentioned by Remy et al. [17]. Concentration of $\mathrm{MeHg}$ is negatively correlated with soil total organic matter and total $\mathrm{S}$ and is influenced by the soil total $\mathrm{Hg}$ concentration [17]. Åkerblom et al. [18] highlighted that long-term chronic $\mathrm{SO}_{4}{ }^{2-}$ deposition at rates similar to those found in polluted areas of Europe and North America increase the capacity of peatlands to methylate $\mathrm{Hg}$ and store $\mathrm{MeHg}$. Competitive relationships between $\mathrm{Hg}$ and other metals in soil were observed by Jing et al. [19], where desorption of adsorbed $\mathrm{Hg}$ increased with elevated concentrations of added $\mathrm{Cu}$ or $\mathrm{Zn}$.

In our investigation, a laboratory batch incubation experiment was conducted with Chernozem and Luvisol differing in their physicochemical parameters and the available nutrient contents. Digestate, the bio-waste originating from biogas production plants, was applied as a S-rich source of organic matter. Alternatively, wood ash from biomass combustion plants was applied as a different source of $S$ and other macroand micronutrients. As proven by Ochecová et al. [20], the plant-availability of the risk elements in the contaminated soil decreased after ash application, whereas the nutrient contents tended to increase. To separate the effect of organic matter and $\mathrm{S}$ in the soil, inorganic source of $\mathrm{S}$, ammonium sulfate, $\left(\mathrm{NH}_{4}\right)_{2} \mathrm{SO}_{4}$, was applied, as well. The main objectives of the study were as follows: (i) to assess the ability of the individual treatments to immobilize $\mathrm{Hg}$ in the artificially contaminated soil and (ii) to evaluate the potential interactions between $\mathrm{Hg}$ sorption in the experimental soil and the mobility of the essential macro- and microelements in these soils.

\section{Materials and Methods}

2.1. Soils and Ameliorative Materials. The following two soils, differing in their physicochemical characteristics, were
TABLE 1: Main physicochemical characteristics of the experimental soils.

\begin{tabular}{lcc}
\hline Soil type & Luvisol & Chernozem \\
NRSC Soil Texture & Silt loam & Silt loam \\
Clay $(<0.002 \mathrm{~mm})[\%]$ & 5.38 & 2.18 \\
Silt $(0.002-0.05 \mathrm{~mm})[\%]$ & 68.14 & 71.80 \\
Sand $(0.05-2 \mathrm{~mm})[\%]$ & 26.48 & 26.03 \\
Location & $50^{\circ} 4^{\prime} 22^{\prime \prime} \mathrm{N}$, & $50^{\circ} 7^{\prime} 40^{\prime \prime} \mathrm{N}$, \\
Altitude (m a.s.l.) & $14^{\circ} 10^{\prime} 19^{\prime \prime} \mathrm{E}$ & $14^{\circ} 22^{\prime} 33^{\prime \prime} \mathrm{E}$ \\
P Mehlich III* $\left(\mathrm{mg} \mathrm{kg}^{-1}\right)$ & 410 & 286 \\
K Mehlich III* $\left(\mathrm{mg} \mathrm{kg}^{-1}\right)$ & 100 & 91 \\
Mg Mehlich III* $\left(\mathrm{mg} \mathrm{kg}^{-1}\right)$ & 80 & 230 \\
Ca Mehlich III* $\left(\mathrm{mg} \mathrm{kg}^{-1}\right)$ & 110 & 240 \\
\hline
\end{tabular}

* Šípková et al. [23].

selected for the experiment: (i) uncontaminated Chernozem with a cation exchange capacity (CEC) of $230 \mathrm{mmol} \mathrm{kg}^{-1}$, a $\mathrm{pH}$ level of 7.5, and an oxidizable carbon content (Cox) of $2.6 \%$, and (ii) uncontaminated Luvisol with a CEC of $145 \mathrm{mmol} \mathrm{kg}^{-1}$, a pH level of 6.5 , and a Cox of $1.7 \%$. Nutrient contents and other characteristics in both soil samples are summarized in Table 1. Soils were sampled from a depth of $20 \mathrm{~cm}$, immediately after which they were homogenized, sieved through a $5 \mathrm{~mm}$ diameter mesh, and kept at room temperature. For the experimental incubation soils, samples were sieved again using a $2 \mathrm{~mm}$ mesh and kept at $4^{\circ} \mathrm{C}$ until use. The fly ash ( $\mathrm{pH} 12.1)$ was produced by the combustion of wood ash produced in two reactors (1.8 MW and 0.6 MW). The digestate sample ( $\mathrm{pH}$ 8.2) originated from a biogas station $(1732 \mathrm{~kW} / \mathrm{h})$, where the digested material consisted of sugar beet pulp (50\%), marc of fruit $(42 \%)$, and silage maize $(8 \%)$. The macro- and micronutrient contents in both ameliorative materials are summarized in Table 2. As an inorganic amendment, solid particles of $\left(\mathrm{NH}_{4}\right)_{2} \mathrm{SO}_{4}$ were used (Reagent from Fisher Scientific).

2.2. Experimental Design. For the experimental incubation soils, $100 \mathrm{~g}$ of Chernozem and Luvisol soils were placed into polypropylene bottles and immediately after were brought to $60 \%$ moisture saturation. Then, half of the soil samples were artificially contaminated with $\mathrm{Hg}$ by adding $60 \mathrm{mg}$ of $\mathrm{HgCl}_{2}$ to reach a concentration of $440 \mathrm{mg} \cdot \mathrm{kg}^{-1}$ of $\mathrm{Hg}$. Subsequently, organic and inorganic amendments: (1) ash, (2) digestate, and (3) $\left(\mathrm{NH}_{4}\right)_{2} \mathrm{SO}_{4}$, were applied both to contaminated and noncontaminated soils. The rate of amendment was calculated for $600 \mathrm{mg} \mathrm{S}$ per kg of soil as follows: (1) ash: $1.5 \mathrm{~g}$, (2) digestate: $10 \mathrm{~g}$, and (3) $\mathrm{NH}_{4} \mathrm{SO}_{4}: 0.25 \mathrm{~g}$ per bottle.

Soils that were contaminated and noncontaminated with $\mathrm{Hg}$ were thoroughly mixed and incubated at $28^{\circ} \mathrm{C}$ for 21 days. To evaluate the mobility of $\mathrm{Hg}$ in both soils and interactions with macro- and micronutrients as well, soil samples were collected after 1, 2, 3, 4, 7, 14, and 21 days of incubation. Three replicates were set up per treatment. 
TABLE 2: Nutrient contents in the dry matter of ameliorative materials.

\begin{tabular}{lcc}
\hline Element & Fly-ash & Digestate \\
\hline $\mathrm{P}(\%)$ & $1.29 \pm 0.01$ & $1.20 \pm 0.01$ \\
$\mathrm{~K}(\%)$ & $7.74 \pm 0.02$ & $2.12 \pm 0.01$ \\
$\mathrm{Mg}(\%)$ & $1.44 \pm 0.02$ & $0.49 \pm 0.02$ \\
$\mathrm{Ca}(\%)$ & $13.4 \pm 0.1$ & $3.15 \pm 0.01$ \\
$\mathrm{~S}(\%)$ & $4.07 \pm 0.01$ & $0.60 \pm 0.01$ \\
$\mathrm{Cu}(\%)$ & $0.020 \pm 0.001$ & $0.004 \pm 0.001$ \\
$\mathrm{Fe}(\%)$ & $2.79 \pm 0.01$ & $0.18 \pm 0.01$ \\
$\mathrm{Mn}(\%)$ & $1.29 \pm 0.01$ & $0.02 \pm 0.00$ \\
$\mathrm{Zn}(\%)$ & $3.58 \pm 0.08$ & $0.03 \pm 0.00$ \\
\hline
\end{tabular}

2.3. Extraction of Soluble Portions of $\mathrm{Hg}$ and Macro- and Micronutrients. For the determination of bioavailable element portions in soils during the experiment, $0.5 \mathrm{~g}$ of each sample was added to $10 \mathrm{~mL}$ of $0.11 \mathrm{~mol} \mathrm{~L}^{-1}$ solution of $\mathrm{CH}_{3} \mathrm{COOH}$ and shaken overnight [21]. Each extraction was carried out in three replicates. For the centrifugation of extracts, a Hettich Universal 30 RF (Germany) instrument was used. The reaction mixture was centrifuged at $3000 \mathrm{rpm}$ (i.e., $460 \mathrm{~g}$ ) for 10 minutes at the end of each extraction procedure, and the supernatants were kept at $6^{\circ} \mathrm{C}$ prior to measurements. Prior to the analysis, extracts were acidified with a mixture of acids $\left(\mathrm{HNO}_{3}: \mathrm{HCl}=3: 1\right)$. For the determination of nutrient status in the experimental soils before the experiment, the Mehlich III extraction procedure $\left(0.2 \mathrm{~mol} \mathrm{~L}^{-1}\right.$ of $\mathrm{CH}_{3} \mathrm{COOH}+0.25 \mathrm{~mol} \mathrm{~L}^{-1}$ of $\mathrm{NH}_{4} \mathrm{NO}_{3}+0.013 \mathrm{~mol} \mathrm{~L}^{-1}$ of $\mathrm{HNO}_{3}+0.015 \mathrm{~mol} \mathrm{~L}^{-1}$ of $\mathrm{NH}_{4} \mathrm{~F}+0.001 \mathrm{~mol} \mathrm{~L}^{-1}$ of EDTA) at the ratio of $1 \mathrm{~g}$ of soil per $10 \mathrm{~mL}$ of the extraction mixture for $10 \mathrm{~min}$ [22] was applied.

2.4. Determination of $\mathrm{Hg}$. $\mathrm{Hg}$ content in the extracts was measured by inductively coupled plasma mass spectrometry (ICP-MS, Agilent 7700x, Agilent Technologies Inc., USA). The auto-sampler ASX-500, a three-channel peristaltic pump, and MicroMist nebulizer equipped the ICP-MS. Calibration solutions were prepared in diluted single element ICP-MS standards as $0.1-100 \mu \mathrm{g} \mathrm{L}^{-1}$ for $\mathrm{Hg}$ and the isotope $\mathrm{Hg}(202)$ was measured. As an internal standard, $\mathrm{Pt}(195)$ was used at the concentration of $100 \mu \mathrm{g} \mathrm{L}^{-1}$.

2.5. Determination of Macro- and Micronutrients. Inductively coupled plasma-atomic emission spectrometry (ICP-OES, Agilent 720, Agilent Technologies Inc., USA) equipped with a two-channel peristaltic pump, a Struman-Masters spray chamber, and a V-groove pneumatic nebulizer made of inert material was applied for the determination of $\mathrm{Cu}, \mathrm{Fe}, \mathrm{Mn}$, $\mathrm{Zn}, \mathrm{P}$, and $\mathrm{S}$ in the extracts (the experimental conditions were as follows: power of $1.2 \mathrm{~kW}$, plasma flow of $15.0 \mathrm{~L} \cdot \mathrm{min}^{-1}$, auxiliary flow of $0.75 \mathrm{~L} \cdot \mathrm{min}^{-1}$, nebulizer flow of $\left.0.9 \mathrm{~L} \cdot \mathrm{min}^{-1}\right)$, whereas flame atomic absorption spectrometry (F-AAS, Varian 280FS, Varian, Australia; air flow of $13.5 \mathrm{~L} \cdot \mathrm{min}^{-1}$, acetylene flow of $2.2 \mathrm{~L} \cdot \mathrm{min}^{-1}$, burner height of $13.5 \mathrm{~mL}$, nebulizer uptake rate of $5 \mathrm{~mL} \cdot \mathrm{min}^{-1}$ ) was used for $\mathrm{Ca}, \mathrm{Mg}$, and $\mathrm{K}$ determination in the extracts.
2.6. Determination of Total Nutrient Contents in the Ameliorative Materials. For determination of total element contents in the ash, nondestructive X-ray fluorescence (XRF) spectrometry (Spectro IQ, Kleve, Germany) was used; the target material was palladium and the target angle from the central ray was $90^{\circ}$. The focal point was a $1 \mathrm{~mm} \times 1 \mathrm{~mm}$ square, and the maximum anode dissipation was $50 \mathrm{~W}$ with $10 \mathrm{cfm}$ forced-air cooling. The instrument was equipped with the Barkla crystal HOPG. The tested samples were pressed into pellets; this involved mixing $4.0 \mathrm{~g}$ of ash (particle size 15$20 \mu \mathrm{m}$ ) with $0.9 \mathrm{~g}$ of the binding additive (HWC Hoechst wax, Germany) for $10 \mathrm{~min}$ with a pressing power of $80 \mathrm{kN}$. The determination was performed in the Institute of Rock Structure and Mechanics, Academy of Sciences of the Czech Republic.

The digestate sample was decomposed by pressurized wet ashing as follows: aliquots $(\sim 0.5 \mathrm{~g})$ of air-dried samples were decomposed in a digestion vessel with $10 \mathrm{~mL}$ of Aqua regia (i.e., nitric and hydrochloric acid mixture in the ratio $1: 3$ ). The mixture was heated in an Ethos 1 (MLS, Germany) microwave assisted wet digestion system for $33 \mathrm{~min}$ at $210^{\circ} \mathrm{C}$. ICP-OES and F-AAS were then applied as described in the previous subchapter.

2.7. Statistics. The data obtained were subjected to Dixon's test for the identification of outliers (significance level $\alpha=$ 0.05) using Microsoft Office Excel 2007 (Microsoft Corporation, USA). Subsequently, one-way analysis of variance was used at the significance level $\alpha=0.05$ using the Statistica 12 program (StatSoft, USA).

\section{Results and Discussion}

3.1. Changes in Hg Mobility in the Treated Soils. The mobile $\mathrm{Hg}$ contents affected by the individual treatments and their variability during the incubation experiment are summarized in Figure 1. In the treatments without artificial Hg application, the mobile $\mathrm{Hg}$ contents were under the detection limit of ICP-MS. Similarly to our previous observations [23], Ruggiero et al. [24] also documented that most of the $\mathrm{Hg}$ in the long-term polluted soils was scarcely mobile and available. The $\mathrm{Hg}$ contents in digestates and fly ash are usually low as well $[25,26]$ and did not affect the mobile portions of $\mathrm{Hg}$ in our experiment. The extractable Hg contents differed according to the physicochemical parameters of the used soils and to the individual treatments. In Chernozem, the extractable $\mathrm{Hg}$ contents were low regardless of the treatment at the beginning and end of incubation. Within the 3rd and 7th day of incubation, the mobile $\mathrm{Hg}$ portions increased in all treatments (including control) except for the digestate. Similar course of $\mathrm{Hg}$ mobility changes were observed by Bower et al. [27] in the experiments studying the mercury adsorption onto pyrite indicating the formation of nonmobile sulfides over time. In the Luvisol, the mobile Hg portions decreased during the incubation, whereas they dropped to the levels reached in Chernozem by the end of the experiment. As stated by Müller et al. [28] soil $\mathrm{Hg}$ contamination can cause reduced microbial biomass at the contaminated sites. 

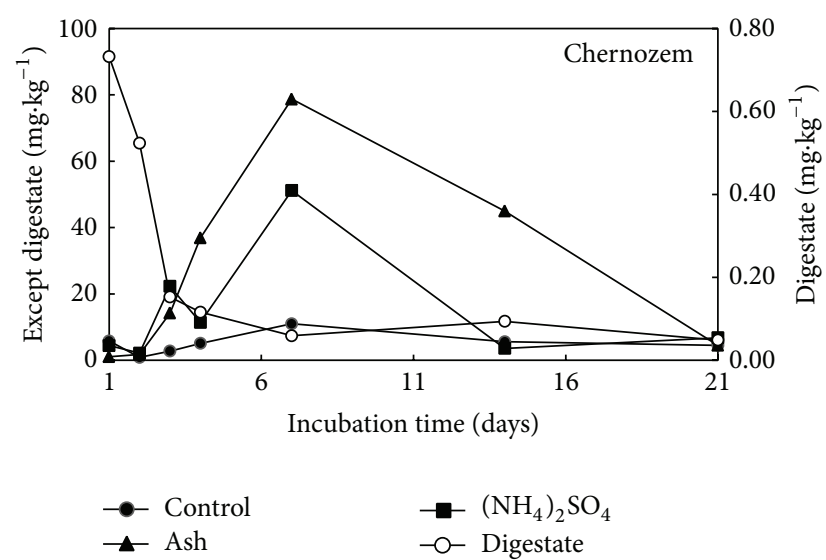

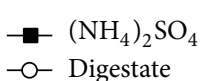

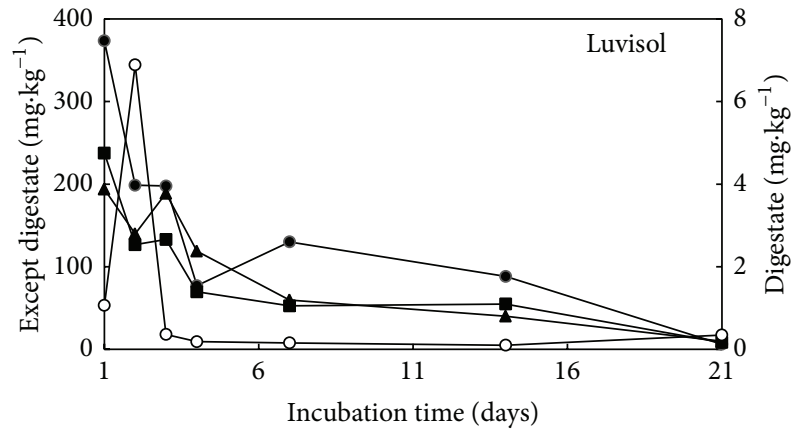

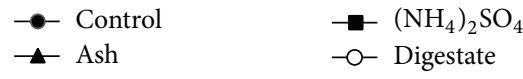

FIGURE 1: The concentrations of $\mathrm{Hg}$ extractable with $0.11 \mathrm{~mol} \mathrm{~L}^{-1}$ acetic acid within the incubation experiment $\left(\mathrm{mg} \cdot \mathrm{kg}^{-1}\right)$ according to the individual treatments.

However, some microorganisms have developed mechanisms to adapt to $\mathrm{Hg}$, that is, $\mathrm{Hg}$-resistant bacteria. Thus, the changes in $\mathrm{Hg}$ mobility observed throughout the experiment could be partially attributed to different communities of soil microorganism present in both Chernozem and Luvisol.

Therefore, among the individual treatments, digestate was shown to be the most effective $\mathrm{Hg}$ immobilizing agent, whereas fly ash seemed to be less effective, and no significant difference was reported comparing the ammonium sulfate treatment and untreated control except the faster increase of mobile $\mathrm{Hg}$ content in $3 \mathrm{rd}$ and 4 th days of the incubation indicating potential role of increased portion of mobile sulfur as mentioned below. The effectiveness of individual treatments as well as the temporal changes in mobile Hg portions were also affected predominantly by the soil where higher sorption capacity and organic matter content in Chernozem resulted in lower mobile portions of $\mathrm{Hg}$ in all the treatments except increased mobility of $\mathrm{Hg}$ after ash application in 7 th and 14th day of the incubation. These results also indicated that $\mathrm{S}$ content in the ameliorative materials was not the main factor controlling the $\mathrm{Hg}$ mobility in the soils. Luo et al. [6] reported a low relationship between $\mathrm{S}$ and $\mathrm{Hg}$ contents in soils with low total organic carbon $(\sim 2 \%)$, as in our case, where the carbon content was not increased by the addition of ammonium sulfate and ash. In the opposite, the $\mathrm{Hg}$ behaviour in soils strongly differed if digestate with high content of both $S$ and total carbon content was applied.

Higher organic carbon content in the soil can enhance both soil microbial activities and the retention of total $\mathrm{Hg}$ and $\mathrm{MeHg}$ in soil [29]. Soil microorganisms need essential metals for their metabolism, which are often required in low concentrations and act as enzyme cofactors [30]. Therefore, high contents of macro- and micronutrients in both ash and digestate (Table 2) can be beneficial for the enhancement of the microbial activity in soils. Limited $\mathrm{Hg}$ mobility via complexation with soil organic matter was already described [9]. Ravichandran [31] reviewed the formation of extremely strong ionic bonds between $\mathrm{Hg}$ and reduced $\mathrm{S}$ sites in soil organic matter supporting the importance of the mutual role of $\mathrm{S}$ and organic matter in $\mathrm{Hg}$ immobilization in soil.
Therefore, the Hg desorption increased with elevating concentrations of dissolved organic matter [10]. In our case, the dissolved organic matter after 1 day of incubation varied between $71.9 \mathrm{mg} \cdot \mathrm{kg}^{-1}$ (control) and $1070 \mathrm{mg} \cdot \mathrm{kg}^{-1}$ (digestate) in Chernozem and between $21.2 \mathrm{mg} \cdot \mathrm{kg}^{-1}$ (control) and $56.4 \mathrm{mg} \cdot \mathrm{kg}^{-1}$ (digestate) in Luvisol. After 7 days of incubation, the DOM contents increased even 22-fold in the digestatetreated Luvisol, whereas the maximum 1.5-fold increase was observed in Chernozem. Therefore, our results indicate that more complex factors can change the $\mathrm{Hg}$ mobility in soil than solely the content and solubility of organic carbon in soil. For example, the affinity of $\mathrm{Hg}$ to bind to metal oxides should be taken into account [32]. Also, the role of some soil bacteria which are able to degrade $\mathrm{Hg}$ compounds into metallic $\mathrm{Hg}$ by the action of specific enzymes encoded by the mer genes and then be released into the surrounding environment should be considered [33]. Thus, the decrease of mobile $\mathrm{Hg}$ in soil could be partially figured in the volatilization of this element during incubation. This assumption remains to be verified in further research. In our investigation, the experiments were concerned on the description of potential decrease of mobile $\mathrm{Hg}$ content without exact resolution between immobilization/volatilization ratios after the individual treatments.

\subsection{The Effect of $\mathrm{Hg}$ and/or Ameliorative Materials on Mobile} Contents of Macro- and Micronutrients in the Soil. The mobile macro- and microelement contents affected by the individual treatments and/or duration of incubation are summarized in Tables 3, 4, 5, 6, 7, 8, 9, 10, and 11. The presence of digestate showed a predominant effect on the mobile portions of most of the elements among all the treatments. The mobile element contents significantly increased after digestate application for most of the determined nutrients, except $\mathrm{Ca}$ and $\mathrm{Cu}$ in Chernozem (because of its low availability in the ameliorative materials). More apparent increase of mobile element contents after application of digestate was observed for Luvisol compared to Chernozem due to higher sorption capacity of Chernozem in accordance with their higher CEC level. For example, Table 4 shows 5 -fold increase of mobile $\mathrm{Mg}$ 
TABLE 3: The concentrations of Ca extractable with $0.11 \mathrm{~mol} \mathrm{~L}^{-1}$ acetic acid within the incubation experiment $\left(\mathrm{mg} \cdot \mathrm{kg}^{-1}\right)$; the averages marked by the same letter did not significantly differ at $P<0.05$ within individual columns; data are presented as mean \pm standard deviation $(n=3)$.

\begin{tabular}{|c|c|c|c|c|c|c|c|}
\hline Chernozem & Day 1 & Day 2 & Day 3 & Day 4 & Day 7 & Day 14 & Day 21 \\
\hline Control & $7555 \pm 331^{\mathrm{a}}$ & $7655 \pm 183^{\mathrm{a}}$ & $8390 \pm a 213^{a}$ & $9674 \pm 219^{\mathrm{a}}$ & $9034 \pm 238^{\mathrm{ab}}$ & $9856 \pm 1191^{\mathrm{ab}}$ & $6040 \pm 270^{\mathrm{a}}$ \\
\hline Control $+\mathrm{Hg}$ & $8074 \pm 260^{\mathrm{a}}$ & $7694 \pm 359^{\mathrm{a}}$ & $7467 \pm \mathrm{a} 677^{\mathrm{a}}$ & $9607 \pm 193^{\mathrm{a}}$ & $8891 \pm 702^{\mathrm{a}}$ & $8951 \pm 236^{\mathrm{ab}}$ & $7865 \pm 983^{\mathrm{abc}}$ \\
\hline Digestate & $8282 \pm 735^{a}$ & $8094 \pm 155^{\mathrm{a}}$ & $8049 \pm \mathrm{a} 687^{\mathrm{a}}$ & $10122 \pm 206^{\mathrm{a}}$ & $8886 \pm 362^{\mathrm{a}}$ & $11004 \pm 926^{\mathrm{b}}$ & $12402 \pm 2330^{\mathrm{bc}}$ \\
\hline Digestate $+\mathrm{Hg}$ & $8108 \pm 232^{\mathrm{a}}$ & $9656 \pm 282^{\mathrm{a}}$ & $7824 \pm \mathrm{a} 454^{\mathrm{a}}$ & $11360 \pm 1521^{\mathrm{a}}$ & $10104 \pm 205^{\mathrm{b}}$ & $10232 \pm 499^{\mathrm{ab}}$ & $11286 \pm 1243^{c}$ \\
\hline Ash & $8448 \pm 548^{\mathrm{a}}$ & $8246 \pm \mathrm{a} 282^{\mathrm{a}}$ & $8746 \pm \mathrm{a} 272^{\mathrm{a}}$ & $9898 \pm 213^{\mathrm{a}}$ & $9661 \pm 466^{\mathrm{ab}}$ & $9633 \pm 203^{\mathrm{ab}}$ & $9835 \pm 2134^{\mathrm{abc}}$ \\
\hline $\mathrm{Ash}+\mathrm{Hg}$ & $8164 \pm 921^{\mathrm{a}}$ & $8072 \pm \mathrm{a} 511^{\mathrm{a}}$ & $8717 \pm \mathrm{a} 611^{\mathrm{a}}$ & $10910 \pm 898^{\mathrm{a}}$ & $9862 \pm 300^{\mathrm{ab}}$ & $10599 \pm 387^{\mathrm{ab}}$ & $9359 \pm 1118^{\mathrm{abc}}$ \\
\hline$\left(\mathrm{NH}_{4}\right)_{2} \mathrm{SO}_{4}$ & $7330 \pm 57^{\mathrm{a}}$ & $7409 \pm \mathrm{a} 201^{\mathrm{a}}$ & $8037 \pm \mathrm{a} 311^{\mathrm{a}}$ & $10134 \pm 1290^{a}$ & $8942 \pm 307^{\mathrm{a}}$ & $8893 \pm 990^{\mathrm{a}}$ & $10045 \pm 2115^{\mathrm{abc}}$ \\
\hline$\left(\mathrm{NH}_{4}\right)_{2} \mathrm{SO}_{4}+\mathrm{Hg}$ & $8041 \pm 796^{\mathrm{a}}$ & $7393 \pm a 359^{a}$ & $8350 \pm 1151^{\mathrm{a}}$ & $9820 \pm 207^{\mathrm{a}}$ & $8991 \pm 382^{\mathrm{ab}}$ & $10238 \pm 790^{\mathrm{ab}}$ & $7031 \pm 3008^{\mathrm{abc}}$ \\
\hline Luvisol & Day 1 & Day 2 & Day 3 & Day 4 & Day 7 & Day 14 & Day 21 \\
\hline Control & $1404 \pm 96^{\mathrm{a}}$ & $1401 \pm 73^{\mathrm{a}}$ & $1372 \pm 56^{\mathrm{a}}$ & $1691 \pm 51^{\mathrm{ab}}$ & $1671 \pm 90^{\mathrm{a}}$ & $1764 \pm 223^{\mathrm{a}}$ & $1273 \pm 125^{\mathrm{a}}$ \\
\hline Control $+\mathrm{Hg}$ & $1450 \pm 93^{\mathrm{a}}$ & $1407 \pm 38^{\mathrm{a}}$ & $1396 \pm 45^{\mathrm{a}}$ & $1635 \pm 52^{\mathrm{a}}$ & $1575 \pm 107^{\mathrm{a}}$ & $1655 \pm 89^{\mathrm{a}}$ & $1274 \pm 283^{\mathrm{a}}$ \\
\hline Digestate & $3558 \pm 121^{\mathrm{b}}$ & $2593 \pm 574^{\mathrm{b}}$ & $2733 \pm 492^{\mathrm{b}}$ & $4086 \pm 116^{\mathrm{d}}$ & $3776 \pm 264^{c}$ & $3294 \pm 380^{\mathrm{b}}$ & $3757 \pm 428^{\mathrm{ab}}$ \\
\hline Digestate $+\mathrm{Hg}$ & $3455 \pm 569^{\mathrm{b}}$ & $3190 \pm 282^{\mathrm{b}}$ & $3139 \pm 328^{\mathrm{b}}$ & $3804 \pm 613^{\mathrm{d}}$ & $4462 \pm 644^{\mathrm{c}}$ & $3975 \pm 206^{c}$ & $4758 \pm 327^{\mathrm{b}}$ \\
\hline Ash & $2335 \pm 433^{\mathrm{a}}$ & $2382 \pm 197^{\mathrm{a}}$ & $2281 \pm 321^{\mathrm{a}}$ & $2540 \pm 234^{b c}$ & $2917 \pm 164^{\mathrm{b}}$ & $2686 \pm 281^{b}$ & $2121 \pm 286 \mathrm{a}^{\mathrm{b}}$ \\
\hline $\mathrm{Ash}+\mathrm{Hg}$ & $1981 \pm 254^{\mathrm{a}}$ & $1908 \pm 149^{\mathrm{a}}$ & $2044 \pm 161^{\mathrm{a}}$ & $2574 \pm 512^{\mathrm{c}}$ & $2717 \pm 117^{\mathrm{b}}$ & $3092 \pm 190^{\mathrm{b}}$ & $2784 \pm 467^{\mathrm{ab}}$ \\
\hline$\left(\mathrm{NH}_{4}\right)_{2} \mathrm{SO}_{4}$ & $1514 \pm 57^{\mathrm{a}}$ & $1356 \pm 36^{\mathrm{a}}$ & $1411 \pm 102^{\mathrm{a}}$ & $1651 \pm 69^{\mathrm{a}}$ & $1597 \pm 79^{\mathrm{a}}$ & $1684 \pm 135^{\mathrm{a}}$ & $1663 \pm 92^{\mathrm{ab}}$ \\
\hline$\left(\mathrm{NH}_{4}\right)_{2} \mathrm{SO}_{4}+\mathrm{Hg}$ & $1655 \pm 54^{\mathrm{a}}$ & $1577 \pm 246^{\mathrm{a}}$ & $1431 \pm 59^{\mathrm{a}}$ & $1742 \pm 108^{\mathrm{abc}}$ & $1616 \pm 32^{\mathrm{a}}$ & $1666 \pm 124^{\mathrm{a}}$ & $1690 \pm 107^{\mathrm{ab}}$ \\
\hline
\end{tabular}

TABLE 4: The concentrations of Mg extractable with $0.11 \mathrm{~mol} \mathrm{~L}^{-1}$ acetic acid within the incubation experiment $\left(\mathrm{mg} \cdot \mathrm{kg}^{-1}\right)$; the averages marked by the same letter did not significantly differ at $P<0.05$ within individual columns; data are presented as mean \pm standard deviation $(n=3)$.

\begin{tabular}{|c|c|c|c|c|c|c|c|}
\hline Chernozem & Day 1 & Day 2 & Day 3 & Day 4 & Day 7 & Day 14 & Day 21 \\
\hline Control & $389 \pm 20^{\mathrm{a}}$ & $401 \pm 2^{\mathrm{ab}}$ & $483 \pm 8^{\mathrm{a}}$ & $562 \pm 18^{\mathrm{a}}$ & $503 \pm 48^{\mathrm{a}}$ & $546 \pm 23^{\mathrm{a}}$ & $371 \pm 50^{\mathrm{a}}$ \\
\hline Control + Hg & $347 \pm 111^{\mathrm{a}}$ & $406 \pm 20^{\mathrm{abc}}$ & $442 \pm 32^{\mathrm{a}}$ & $556 \pm 16^{\mathrm{a}}$ & $502 \pm 69^{\mathrm{a}}$ & $505 \pm 34^{\mathrm{a}}$ & $533 \pm 135^{\mathrm{ab}}$ \\
\hline Digestate & $544 \pm 50^{c}$ & $544 \pm 30^{\mathrm{d}}$ & $603 \pm 65^{b}$ & $753 \pm 52^{b c}$ & $656 \pm 76^{\mathrm{ab}}$ & $781 \pm 54^{\mathrm{c}}$ & $963 \pm 155^{c}$ \\
\hline Digestate $+\mathrm{Hg}$ & $519 \pm 37^{\mathrm{c}}$ & $603 \pm 24^{\mathrm{e}}$ & $610 \pm 45^{\mathrm{b}}$ & $809 \pm 44^{\mathrm{d}}$ & $734 \pm 73^{b}$ & $742 \pm 22^{\mathrm{bc}}$ & $859 \pm 77^{\mathrm{bc}}$ \\
\hline Ash & $442 \pm 24^{\mathrm{ab}}$ & $458 \pm 27^{\mathrm{C}}$ & $522 \pm 22^{\mathrm{ab}}$ & $612 \pm 22^{\mathrm{ac}}$ & $566 \pm 56^{\mathrm{a}}$ & $574 \pm 66^{\mathrm{a}}$ & $636 \pm 147^{\mathrm{abc}}$ \\
\hline $\mathrm{Ash}+\mathrm{Hg}$ & $432 \pm 57^{\mathrm{ab}}$ & $447 \pm 9^{b c}$ & $518 \pm 35^{\mathrm{ab}}$ & $681 \pm 72^{\mathrm{ab}}$ & $555 \pm 31^{\mathrm{a}}$ & $626 \pm 62^{\mathrm{ab}}$ & $585 \pm 122^{\mathrm{ab}}$ \\
\hline$\left(\mathrm{NH}_{4}\right)_{2} \mathrm{SO}_{4}$ & $374 \pm 3^{\mathrm{a}}$ & $394 \pm 16^{\mathrm{ab}}$ & $461 \pm 13^{\mathrm{a}}$ & $572 \pm 72^{\mathrm{a}}$ & $506 \pm 59^{\mathrm{a}}$ & $494 \pm 71^{\mathrm{a}}$ & $626 \pm 171^{\mathrm{abc}}$ \\
\hline$\left(\mathrm{NH}_{4}\right)_{2} \mathrm{SO}_{4}+\mathrm{Hg}$ & $406 \pm 30^{\mathrm{ab}}$ & $390 \pm 10^{\mathrm{a}}$ & $468 \pm 32^{\mathrm{a}}$ & $566 \pm 10^{\mathrm{a}}$ & $505 \pm 45^{\mathrm{a}}$ & $553 \pm 39^{\mathrm{a}}$ & $489 \pm 119^{\mathrm{a}}$ \\
\hline Luvisol & Day 1 & Day 2 & Day 3 & Day 4 & Day 7 & Day 14 & Day 21 \\
\hline Control & $65 \pm 5^{\mathrm{a}}$ & $72 \pm 5^{a}$ & $71 \pm 2^{a}$ & $89 \pm 3^{a}$ & $120 \pm 47^{\mathrm{a}}$ & $129 \pm 61^{\mathrm{a}}$ & $89 \pm 19^{a}$ \\
\hline Control + Hg & $70 \pm 4^{\mathrm{a}}$ & $72 \pm 2^{\mathrm{a}}$ & $73 \pm 1^{\mathrm{a}}$ & $86 \pm 3^{\mathrm{a}}$ & $108 \pm 43^{\mathrm{a}}$ & $115 \pm 45^{\mathrm{a}}$ & $82 \pm 11^{\mathrm{a}}$ \\
\hline Digestate & $362 \pm 27^{\mathrm{c}}$ & $259 \pm 70^{c}$ & $325 \pm 52^{\mathrm{b}}$ & $446 \pm 5^{c}$ & $408 \pm 40^{\mathrm{b}}$ & $391 \pm 51^{\mathrm{b}}$ & $423 \pm 11^{\mathrm{c}}$ \\
\hline Digestate $+\mathrm{Hg}$ & $364 \pm 89^{c}$ & $336 \pm 38^{\mathrm{c}}$ & $363 \pm 92^{\mathrm{b}}$ & $460 \pm 54^{\mathrm{c}}$ & $476 \pm 28^{\mathrm{b}}$ & $416 \pm 33^{\mathrm{b}}$ & $366 \pm 90^{c}$ \\
\hline Ash & $144 \pm 32^{\mathrm{b}}$ & $156 \pm 19^{\mathrm{b}}$ & $162 \pm 34^{\mathrm{ab}}$ & $176 \pm 21^{b}$ & $231 \pm 51^{\mathrm{a}}$ & $214 \pm 66^{\mathrm{a}}$ & $174 \pm 40^{\mathrm{ab}}$ \\
\hline $\mathrm{Ash}+\mathrm{Hg}$ & $116 \pm 19^{\mathrm{b}}$ & $121 \pm 14^{\mathrm{ab}}$ & $140 \pm 21^{\mathrm{ab}}$ & $178 \pm 47^{\mathrm{b}}$ & $214 \pm 52^{\mathrm{a}}$ & $243 \pm 31^{\mathrm{a}}$ & $240 \pm 33^{\mathrm{b}}$ \\
\hline$\left(\mathrm{NH}_{4}\right)_{2} \mathrm{SO}_{4}$ & $73 \pm 0^{\mathrm{a}}$ & $68 \pm 0^{\mathrm{a}}$ & $72 \pm 5^{\mathrm{a}}$ & $85 \pm 1^{\mathrm{a}}$ & $120 \pm 49^{\mathrm{a}}$ & $114 \pm 43^{\mathrm{a}}$ & $120 \pm 33^{\mathrm{a}}$ \\
\hline$\left(\mathrm{NH}_{4}\right)_{2} \mathrm{SO}_{4}+\mathrm{Hg}$ & $85 \pm 9^{a}$ & $74 \pm 5^{\mathrm{ab}}$ & $76 \pm 2^{\mathrm{ab}}$ & $92 \pm 7^{\mathrm{a}}$ & $115 \pm 46^{\mathrm{a}}$ & $119 \pm 50^{\mathrm{a}}$ & $117 \pm 38^{\mathrm{a}}$ \\
\hline
\end{tabular}

contents in the digestate treated Luvisol compared to up to $40 \%$ increase of mobile $\mathrm{Mg}$ in Chernozem.

Möller and Müller [34] reviewed recent research about nutrient availability after the field application of digestate and stated that there is no available information concerning the availability of $S$, although digestate seems to be a good source of $\mathrm{S}$ in soil; this was also observed in our case (Table 2) where the $S$ content in the digestate sample reached up to $0.6 \%$. Similarly, they stated that there were many published studies describing the effect of anaerobic digestion on micronutrient distribution and bioavailability in sewage sludge, but rarely any concerning digestates. Moreover, the availability of micronutrients in the digestate can be affected by the wide complex of various factors such as precipitation as sulfide, carbonate, phosphates, and hydroxides, sorption to the solid fraction, either biomass or inert suspended matter, and the formation of complexes in solution with intermediates and compounds produced during anaerobic digestion [34]. The application of digestate results in an improvement of crop yields compared to inorganic fertilizer. Moreover, analysis of soil solution showed that there was less potential for the loss of nutrients via leaching [35] in the digestate treated soil. 
TABLE 5: The concentrations of $\mathrm{K}$ extractable with $0.11 \mathrm{~mol} \mathrm{~L}^{-1}$ acetic acid within the incubation experiment $\left(\mathrm{mg} \cdot \mathrm{kg}^{-1}\right)$; the averages marked by the same letter did not significantly differ at $P<0.05$ within individual columns; data are presented as mean \pm standard deviation $(n=3)$.

\begin{tabular}{|c|c|c|c|c|c|c|c|}
\hline Chernozem & Day 1 & Day 2 & Day 3 & Day 4 & Day 7 & Day 14 & Day 21 \\
\hline Control & $68 \pm 5^{a}$ & $78 \pm 4^{\mathrm{a}}$ & $78 \pm 2^{a}$ & $84 \pm 2^{\mathrm{a}}$ & $92 \pm 4^{\mathrm{a}}$ & $95 \pm 0^{\mathrm{a}}$ & $53 \pm 3^{\mathrm{a}}$ \\
\hline Control $+\mathrm{Hg}$ & $83 \pm 17^{\mathrm{a}}$ & $76 \pm 4^{\mathrm{a}}$ & $77 \pm 10^{\mathrm{a}}$ & $87 \pm 3^{\mathrm{a}}$ & $90 \pm 6^{\mathrm{a}}$ & $94 \pm 3^{\mathrm{a}}$ & $76 \pm 12^{\mathrm{a}}$ \\
\hline Digestate & $2882 \pm 906^{\mathrm{b}}$ & $2931 \pm 491^{\mathrm{b}}$ & $3026 \pm 304^{\mathrm{b}}$ & $3547 \pm 163^{\mathrm{b}}$ & $3615 \pm 177^{\mathrm{c}}$ & $3842 \pm 277^{\mathrm{c}}$ & $4408 \pm 506^{\mathrm{b}}$ \\
\hline Digestate $+\mathrm{Hg}$ & $2461 \pm 510^{\mathrm{b}}$ & $3163 \pm 128^{\mathrm{b}}$ & $2961 \pm 261^{b}$ & $3915 \pm 370^{\mathrm{b}}$ & $3780 \pm 164^{\mathrm{d}}$ & $3697 \pm 191^{c}$ & $4283 \pm 367^{b}$ \\
\hline Ash & $269 \pm 66^{\mathrm{a}}$ & $284 \pm 40^{\mathrm{a}}$ & $294 \pm 59^{\mathrm{a}}$ & $317 \pm 78^{\mathrm{a}}$ & $374 \pm 35^{\mathrm{cd}}$ & $362 \pm 18^{\mathrm{ab}}$ & $406 \pm 146^{\mathrm{a}}$ \\
\hline $\mathrm{Ash}+\mathrm{Hg}$ & $260 \pm 61^{\mathrm{a}}$ & $305 \pm 77^{\mathrm{a}}$ & $310 \pm 47^{\mathrm{a}}$ & $467 \pm 101^{\mathrm{a}}$ & $362 \pm 25^{\mathrm{bc}}$ & $446 \pm 63^{\mathrm{b}}$ & $359 \pm 82^{\mathrm{a}}$ \\
\hline$\left(\mathrm{NH}_{4}\right)_{2} \mathrm{SO}_{4}$ & $97 \pm 5^{\mathrm{a}}$ & $119 \pm 11^{\mathrm{a}}$ & $107 \pm 6^{a}$ & $130 \pm 13^{\mathrm{a}}$ & $126 \pm 6^{\mathrm{ab}}$ & $117 \pm 13^{\mathrm{ab}}$ & $109 \pm 6^{\mathrm{a}}$ \\
\hline$\left(\mathrm{NH}_{4}\right)_{2} \mathrm{SO}_{4}+\mathrm{Hg}$ & $105 \pm 6^{\mathrm{a}}$ & $109 \pm 4^{\mathrm{a}}$ & $112 \pm 6^{\mathrm{a}}$ & $135 \pm 2^{\mathrm{a}}$ & $130 \pm 5^{\mathrm{abc}}$ & $145 \pm 10^{\mathrm{ab}}$ & $1568 \pm 207^{\mathrm{a}}$ \\
\hline Luvisol & Day 1 & Day 2 & Day 3 & Day 4 & Day 7 & Day 14 & Day 21 \\
\hline Control & $117 \pm 7^{\mathrm{a}}$ & $126 \pm 7^{\mathrm{a}}$ & $117 \pm 3^{\mathrm{a}}$ & $140 \pm 4^{\mathrm{a}}$ & $138 \pm 2^{\mathrm{a}}$ & $147 \pm 9^{\mathrm{a}}$ & $111 \pm 12^{\mathrm{a}}$ \\
\hline Control + Hg & $122 \pm 6^{\mathrm{a}}$ & $130 \pm 6^{\mathrm{a}}$ & $125 \pm 4^{\mathrm{a}}$ & $139 \pm 4^{\mathrm{a}}$ & $138 \pm 5^{\mathrm{a}}$ & $146 \pm 3^{\mathrm{a}}$ & $122 \pm 21^{\mathrm{a}}$ \\
\hline Digestate & $3324 \pm 201^{\mathrm{b}}$ & $2684 \pm 425^{\mathrm{b}}$ & $3173 \pm 54^{\mathrm{b}}$ & $3857 \pm 252^{\mathrm{b}}$ & $3936 \pm 37^{\mathrm{c}}$ & $3665 \pm 83^{c}$ & $4063 \pm 418^{c}$ \\
\hline Digestate $+\mathrm{Hg}$ & $3728 \pm 541^{\mathrm{b}}$ & $3306 \pm 214^{\mathrm{b}}$ & $3351 \pm 540^{\mathrm{b}}$ & $4065 \pm 150^{\mathrm{b}}$ & $3927 \pm 308^{c}$ & $3655 \pm 64^{c}$ & $3304 \pm 180^{\mathrm{b}}$ \\
\hline Ash & $431 \pm 146^{\mathrm{a}}$ & $487 \pm 78^{\mathrm{a}}$ & $431 \pm 111^{\mathrm{a}}$ & $419 \pm 70^{\mathrm{a}}$ & $548 \pm 66^{\mathrm{b}}$ & $446 \pm 71^{\mathrm{b}}$ & $387 \pm 18^{\mathrm{a}}$ \\
\hline $\mathrm{Ash}+\mathrm{Hg}$ & $316 \pm 70^{\mathrm{a}}$ & $343 \pm 41^{\mathrm{a}}$ & $370 \pm 39^{a}$ & $454 \pm 102^{\mathrm{a}}$ & $489 \pm 15^{\mathrm{b}}$ & $546 \pm 66^{\mathrm{b}}$ & $553 \pm 118^{\mathrm{a}}$ \\
\hline$\left(\mathrm{NH}_{4}\right)_{2} \mathrm{SO}_{4}$ & $152 \pm 3^{\mathrm{a}}$ & $145 \pm 5^{\mathrm{a}}$ & $143 \pm 11^{\mathrm{a}}$ & $162 \pm 1^{\mathrm{a}}$ & $161 \pm 5^{\mathrm{a}}$ & $167 \pm 9^{\mathrm{a}}$ & $166 \pm 17^{\mathrm{a}}$ \\
\hline$\left(\mathrm{NH}_{4}\right)_{2} \mathrm{SO}_{4}+\mathrm{Hg}$ & $159 \pm 6^{\mathrm{a}}$ & $158 \pm 9^{\mathrm{a}}$ & $152 \pm 4^{\mathrm{a}}$ & $176 \pm 9^{\mathrm{a}}$ & $169 \pm 4^{\mathrm{a}}$ & $162 \pm 4^{\mathrm{a}}$ & $170 \pm 14^{\mathrm{a}}$ \\
\hline
\end{tabular}

TABLE 6: The concentrations of $\mathrm{Cu}$ extractable with $0.11 \mathrm{~mol} \mathrm{~L}^{-1}$ acetic acid within the incubation experiment $\left(\mathrm{mg} \cdot \mathrm{kg}^{-1}\right)$; the averages marked by the same letter did not significantly differ at $P<0.05$ within individual columns; data are presented as mean \pm standard deviation $(n=3)$.

\begin{tabular}{|c|c|c|c|c|c|c|c|}
\hline Chernozem & Day 1 & Day 2 & Day 3 & & Day 7 & & \\
\hline Cont & $.045 \pm 0.007^{\mathrm{a}}$ & $.039 \pm 0.008^{\mathrm{a}}$ & $0.015 \pm 0.003^{\mathrm{a}}$ & $0.025 \pm 0.003^{\mathrm{a}}$ & $0.162 \pm 0.018^{\mathrm{abc}}$ & $0.064 \pm 0.013^{\mathrm{a}}$ & $0.017 \pm 0.008^{\mathrm{a}}$ \\
\hline & & & & & & & \\
\hline Digestate & & & & & & & \\
\hline $\mathrm{te}+\mathrm{Hg}$ & & & & & & $0.334 \pm 0.031^{\mathrm{b}}$ & $0.763 \pm 0.065^{\mathrm{b}}$ \\
\hline Ash & & & & & & & \\
\hline $\mathrm{Hg}$ & $70+0$ & $0.042 \pm 0.003^{\mathrm{a}}$ & $0.026 \pm 0.005^{\mathrm{a}}$ & $0.060 \pm 0.013^{\mathrm{a}}$ & $0.055 \pm 0.035^{\mathrm{a}}$ & $0.095 \pm 0.027^{\mathrm{a}}$ & $0.141 \pm 0.069^{\mathrm{a}}$ \\
\hline$\left.{ }_{4}\right) \mathrm{SO}_{4}$ & $.047 \pm 0.035^{\mathrm{a}}$ & $0.048 \pm 0.013^{\mathrm{a}}$ & $0.018 \pm 0.006^{\mathrm{a}}$ & $0.022 \pm 0.006^{\mathrm{a}}$ & $0.081 \pm 0.031^{\mathrm{ab}}$ & $0.091 \pm 0.038^{\mathrm{a}}$ & $0.090 \pm 0.060^{\mathrm{a}}$ \\
\hline $\mathrm{SO}_{4}+\mathrm{Hg}$ & $0.038 \pm 0.020^{\mathrm{a}}$ & $0.029 \pm 0.007^{\mathrm{a}}$ & $0.008 \pm 0.008^{\mathrm{a}}$ & $0.029 \pm 0.002^{\mathrm{a}}$ & $0.029 \pm 0.013^{\mathrm{a}}$ & $0.066 \pm 0.048^{\mathrm{a}}$ & $0.379 \pm 0.093^{\mathrm{ab}}$ \\
\hline & Day 1 & Day 2 & Day 3 & Day 4 & Day 7 & & \\
\hline & & & & & 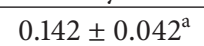 & & \\
\hline & & & & & & & \\
\hline & & & & & & & \\
\hline Digestate $+\mathrm{Hg}$ & & & & & & & \\
\hline Ash & & $0.161 \pm 0.036^{\mathrm{ab}}$ & $0.145 \pm 0.023^{\mathrm{ab}}$ & $0.269 \pm 0.051^{\mathrm{ab}}$ & $0.220 \pm 0.045^{\mathrm{a}}$ & $0.542 \pm 0.046^{\mathrm{bc}}$ & $0.493 \pm 0.081^{\mathrm{ab}}$ \\
\hline Ash $+\mathrm{Hg}$ & $225+004 \mathrm{~g}^{\mathrm{ab}}$ & $0.261 \pm 0.024^{\mathrm{b}}$ & $0.193 \pm 0.016^{\mathrm{ab}}$ & $0.298 \pm 0.045^{\mathrm{b}}$ & $0.266 \pm 0.040^{\mathrm{a}}$ & $0.578 \pm 0.058^{\mathrm{c}}$ & $0.900 \pm 0.042^{\mathrm{bc}}$ \\
\hline & $0.101 \pm 0.022^{\mathrm{a}}$ & $0.191 \pm 0.048^{\mathrm{ab}}$ & $0.078 \pm 0.004^{\mathrm{a}}$ & $0.184 \pm 0.018^{\mathrm{ab}}$ & $0.161 \pm 0.024^{\mathrm{a}}$ & & $0.658 \pm 0.103^{\mathrm{ab}}$ \\
\hline$\left(\mathrm{NH}_{4}\right)_{2} \mathrm{SO}_{4}+\mathrm{Hg}$ & $0.140 \pm 0.027^{\mathrm{a}}$ & $0.138 \pm 0.028^{\mathrm{ab}}$ & $0.121 \pm 0.014^{\mathrm{a}}$ & $0.247 \pm 0.068^{\mathrm{ab}}$ & $0.193 \pm 0.050^{\mathrm{a}}$ & $0.422 \pm 0.101^{\mathrm{abc}}$ & $0.555 \pm 0.062^{\mathrm{ab}}$ \\
\hline
\end{tabular}

Also, Frøseth et al. [36] observed that the field application of digestate contributed to higher soil aggregate stability. According to Fernández-Delgado Juarez et al. [37], amending soils with digestate resulted in a higher nutrient content as well as more efficient soil microbial community relative to the variants treated with farmyard manure. Therefore, the application of digestate seemed to be the effective measure for immobilization of $\mathrm{Hg}$ in soil together with increase of mobile nutrients in these soils.

The application of wood fly ash as a potential source of available nutrients in the soil is widely discussed in the literature $[38,39]$. The benefits on the growth of the plants as the result of an increase in available $\mathrm{P}, \mathrm{Ca}, \mathrm{Mg}, \mathrm{K}$, and $\mathrm{B}$ and a decrease in $\mathrm{Al}$ toxicity was described [38]. Steenari et al. [40] tested the release of macro- and microelements from various ash samples, whereas low leaching rates were observed for the important plant nutrients $\mathrm{P}$ and $\mathrm{Mg}$, as well as for $\mathrm{Fe}, \mathrm{Mn}, \mathrm{Cu}$, and $\mathrm{Zn}$, up to $50 \%$ of total $\mathrm{K}$ was released during the batch leaching test. In our case, the extractable element contents in the ash amended samples differed according to the experimental soil, where $\mathrm{Ca}, \mathrm{Fe}$, and $\mathrm{Cu}$ levels remained unchanged compared to the control. 


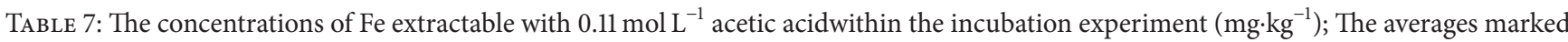
by the same letter did not significantly differ at $P<0.05$ within individual columns; data are presented as mean \pm standard deviation $(n=3)$.

\begin{tabular}{|c|c|c|c|c|c|c|c|}
\hline Chernozem & Day 1 & Day 2 & Day 3 & Day 4 & Day 7 & Day 14 & Day 21 \\
\hline Control & $1.54 \pm 0.38^{\mathrm{a}}$ & $20.47 \pm 6.26^{\mathrm{a}}$ & $8.49 \pm 0.70^{\mathrm{a}}$ & $0.28 \pm 0.02^{\mathrm{a}}$ & $0.48 \pm 0.11^{\mathrm{a}}$ & $4.52 \pm 0.24^{\mathrm{a}}$ & $0.25 \pm 0.06^{\mathrm{a}}$ \\
\hline Control + Hg & $1.40 \pm 0.09^{\mathrm{a}}$ & $8.20 \pm 2.34^{\mathrm{a}}$ & $10.76 \pm 8.02^{\mathrm{a}}$ & $0.18 \pm 0.03^{\mathrm{a}}$ & $0.20 \pm 0.03^{\mathrm{a}}$ & $2.90 \pm 1.05^{\mathrm{a}}$ & $0.24 \pm 0.04^{\mathrm{a}}$ \\
\hline Digestate & $49.3 \pm 9.4^{c}$ & $95.4 \pm 17.2^{c}$ & $105.9 \pm 2.6^{\mathrm{b}}$ & $142.5 \pm 11.7^{\mathrm{c}}$ & $102.4 \pm 2.7^{\mathrm{c}}$ & $32.4 \pm 5.3^{\mathrm{b}}$ & $48.7 \pm 6.4^{\mathrm{b}}$ \\
\hline Digestate + Hg & $27.0 \pm 4.2^{\mathrm{b}}$ & $61.9 \pm 15.2^{\mathrm{b}}$ & $77.1 \pm 28.8^{\mathrm{b}}$ & $73.1 \pm 10.7^{\mathrm{b}}$ & $69.4 \pm 5.5^{\mathrm{b}}$ & $48.0 \pm 14.2^{c}$ & $48.3 \pm 9.6^{\mathrm{b}}$ \\
\hline Ash & $1.31 \pm 0.16^{\mathrm{a}}$ & $28.78 \pm 5.86^{\mathrm{a}}$ & $6.87 \pm 1.97^{\mathrm{a}}$ & $0.26 \pm 0.10^{\mathrm{a}}$ & $0.35 \pm 0.11^{\mathrm{a}}$ & $1.53 \pm 0.17^{\mathrm{a}}$ & $0.90 \pm 0.24^{\mathrm{a}}$ \\
\hline $\mathrm{Ash}+\mathrm{Hg}$ & $1.16 \pm 0.46^{\mathrm{a}}$ & $8.17 \pm 2.01^{\mathrm{a}}$ & $7.58 \pm 4.58^{\mathrm{a}}$ & $0.30 \pm 0.11^{\mathrm{a}}$ & $0.28 \pm 0.04^{\mathrm{a}}$ & $1.07 \pm 0.10^{\mathrm{a}}$ & $0.06 \pm 0.03^{\mathrm{a}}$ \\
\hline$\left(\mathrm{NH}_{4}\right)_{2} \mathrm{SO}_{4}$ & $1.29 \pm 0.15^{\mathrm{a}}$ & $17.20 \pm 5.83^{\mathrm{a}}$ & $5.53 \pm 1.19^{\mathrm{a}}$ & $0.35 \pm 0.17^{\mathrm{a}}$ & $0.26 \pm 0.06^{\mathrm{a}}$ & $3.91 \pm 1.32^{\mathrm{a}}$ & $0.15 \pm 0.12^{\mathrm{a}}$ \\
\hline$\left(\mathrm{NH}_{4}\right)_{2} \mathrm{SO}_{4}+\mathrm{Hg}$ & $1.13 \pm 0.28^{\mathrm{a}}$ & $10.53 \pm 3.15^{\mathrm{a}}$ & $7.21 \pm 2.97^{\mathrm{a}}$ & $0.14 \pm 0.09^{\mathrm{a}}$ & $0.23 \pm 0.03^{\mathrm{a}}$ & $1.53 \pm 0.19^{\mathrm{a}}$ & $2.37 \pm 0.36^{\mathrm{a}}$ \\
\hline Luvisol & Day 1 & Day 2 & Day 3 & Day 4 & Day 7 & Day 14 & Day 21 \\
\hline Control & $3.88 \pm 2.13^{\mathrm{a}}$ & $20.08 \pm 6.85^{\mathrm{a}}$ & $7.35 \pm 1.27^{\mathrm{a}}$ & $1.31 \pm 0.18^{\mathrm{a}}$ & $1.04 \pm 0.14^{\mathrm{a}}$ & $7.17 \pm 2.64^{\mathrm{a}}$ & $1.13 \pm 0.66^{\mathrm{a}}$ \\
\hline Control $+\mathrm{Hg}$ & $2.21 \pm 0.27^{\mathrm{a}}$ & $10.02 \pm 4.27^{\mathrm{a}}$ & $12.24 \pm 2.19^{\mathrm{a}}$ & $1.38 \pm 0.31^{\mathrm{a}}$ & $0.91 \pm 0.08^{\mathrm{a}}$ & $5.99 \pm 0.76^{\mathrm{a}}$ & $0.67 \pm 0.47^{\mathrm{a}}$ \\
\hline Digestate & $100.8 \pm 33.1^{\mathrm{b}}$ & $51.9 \pm 25.4^{\mathrm{b}}$ & $67.6 \pm 40.6^{\mathrm{ab}}$ & $44.7 \pm 14.3^{\mathrm{b}}$ & $77.4 \pm 14.5^{\mathrm{b}}$ & $42.5 \pm 13.0^{\mathrm{a}}$ & $173.5 \pm 71.0^{\mathrm{b}}$ \\
\hline Digestate $+\mathrm{Hg}$ & $108.0 \pm 38.7^{b}$ & $340.9 \pm 82.3^{b}$ & $329.4 \pm 70.4^{\mathrm{b}}$ & $413.7 \pm 52.8^{\mathrm{c}}$ & $484.7 \pm 97.2^{\mathrm{C}}$ & $396.9 \pm 54.1^{\mathrm{b}}$ & $315.4 \pm 63.8^{c}$ \\
\hline Ash & $2.80 \pm 0.70^{\mathrm{a}}$ & $16.71 \pm 3.74^{\mathrm{a}}$ & $15.41 \pm 3.44^{\mathrm{a}}$ & $1.82 \pm 0.59^{\mathrm{a}}$ & $1.58 \pm 0.77^{\mathrm{a}}$ & $7.44 \pm 2.02^{\mathrm{a}}$ & $2.86 \pm 1.43^{\mathrm{a}}$ \\
\hline $\mathrm{Ash}+\mathrm{Hg}$ & $2.56 \pm 0.27^{\mathrm{a}}$ & $15.88 \pm 9.53^{\mathrm{a}}$ & $11.24 \pm 4.10^{\mathrm{a}}$ & $1.21 \pm 0.44^{\mathrm{a}}$ & $0.99 \pm 0.18^{\mathrm{a}}$ & $2.94 \pm 1.18^{\mathrm{a}}$ & $0.59 \pm 0.05^{\mathrm{a}}$ \\
\hline$\left(\mathrm{NH}_{4}\right)_{2} \mathrm{SO}_{4}$ & $3.07 \pm 0.09^{\mathrm{a}}$ & $8.82 \pm 0.53^{\mathrm{a}}$ & $7.06 \pm 2.55^{\mathrm{a}}$ & $1.61 \pm 0.21^{\mathrm{a}}$ & $1.28 \pm 0.07^{\mathrm{a}}$ & $5.68 \pm 1.15^{\mathrm{a}}$ & $1.64 \pm 0.30^{\mathrm{a}}$ \\
\hline$\left(\mathrm{NH}_{4}\right)_{2} \mathrm{SO}_{4}+\mathrm{Hg}$ & $3.01 \pm 0.32^{\mathrm{a}}$ & $10.36 \pm 2.32^{\mathrm{a}}$ & $14.56 \pm 2.55^{\mathrm{a}}$ & $1.59 \pm 0.21^{\mathrm{a}}$ & $1.39 \pm 0.24^{\mathrm{a}}$ & $2.47 \pm 0.42^{\mathrm{a}}$ & $1.02 \pm 0.23^{\mathrm{a}}$ \\
\hline
\end{tabular}

TABLE 8: The concentrations of Mn extractable with $0.11 \mathrm{~mol} \mathrm{~L}{ }^{-1}$ acetic acid within the incubation experiment $\left(\mathrm{mg} \cdot \mathrm{kg}^{-1}\right)$; the averages marked by the same letter did not significantly differ at $P<0.05$ within individual columns; data are presented as mean \pm standard deviation $(n=3)$.

\begin{tabular}{|c|c|c|c|c|c|c|c|}
\hline Chernozem & Day 1 & Day 2 & Day 3 & Day 4 & Day 7 & Day 14 & Day 21 \\
\hline Control & $19.5 \pm 1.2^{\mathrm{a}}$ & $19.9 \pm 0.7^{\mathrm{a}}$ & $22.2 \pm 1.1^{\mathrm{a}}$ & $35.0 \pm 6.1^{\mathrm{a}}$ & $33.9 \pm 0.9^{\mathrm{a}}$ & $46.7 \pm 16.0^{\mathrm{a}}$ & $34.7 \pm 8.7^{\mathrm{a}}$ \\
\hline Control $+\mathrm{Hg}$ & $21.4 \pm 4.4^{\mathrm{a}}$ & $22.1 \pm 3.4^{\mathrm{ab}}$ & $20.7 \pm 3.9^{\mathrm{a}}$ & $36.2 \pm 4.8^{\mathrm{a}}$ & $36.6 \pm 0.3^{\mathrm{a}}$ & $37.3 \pm 5.0^{c}$ & $37.8 \pm 11.6^{\mathrm{a}}$ \\
\hline Digestate & $168 \pm 22^{c}$ & $168 \pm 12^{c}$ & $177 \pm 10^{\mathrm{c}}$ & $232 \pm 4^{\mathrm{d}}$ & $204 \pm 4^{\mathrm{c}}$ & $218 \pm 11^{\mathrm{a}}$ & $301 \pm 68^{\mathrm{d}}$ \\
\hline Digestate $+\mathrm{Hg}$ & $152 \pm 4^{\mathrm{c}}$ & $181 \pm 6^{c}$ & $168 \pm 4^{\mathrm{c}}$ & $229 \pm 23^{\mathrm{d}}$ & $204 \pm 5^{c}$ & $208 \pm 3^{c}$ & $266 \pm 30^{\mathrm{cd}}$ \\
\hline Ash & $42.4 \pm 7.3^{\mathrm{b}}$ & $38.7 \pm 9.8^{\mathrm{ab}}$ & $57.5 \pm 21.7^{\mathrm{b}}$ & $70.2 \pm 8.5^{\mathrm{bc}}$ & $66.3 \pm 10.6^{b}$ & $66.9 \pm 14.0^{\mathrm{a}}$ & $101.5 \pm 53.7^{\mathrm{ab}}$ \\
\hline $\mathrm{Ash}+\mathrm{Hg}$ & $38.5 \pm 9.2^{\mathrm{b}}$ & $40.0 \pm 4.4^{\mathrm{b}}$ & $46.1 \pm 7.0 \mathrm{a}^{\mathrm{b}}$ & $96.8 \pm 18.0^{c}$ & $73.9 \pm 6.5^{b}$ & $93.1 \pm 15.5^{\mathrm{ab}}$ & $83.0 \pm 32.3^{\mathrm{ab}}$ \\
\hline$\left(\mathrm{NH}_{4}\right)_{2} \mathrm{SO}_{4}$ & $23.8 \pm 1.5^{\mathrm{a}}$ & $24.1 \pm 1.6^{\mathrm{ab}}$ & $27.0 \pm 0.7^{\mathrm{a}}$ & $46.7 \pm 5.0^{\mathrm{ab}}$ & $69.7 \pm 16.6^{\mathrm{b}}$ & $143.1 \pm 19.7^{\mathrm{b}}$ & $125.6 \pm 36.1^{b c}$ \\
\hline$\left(\mathrm{NH}_{4}\right)_{2} \mathrm{SO}_{4}+\mathrm{Hg}$ & $26.4 \pm 8.5^{\mathrm{a}}$ & $28.0 \pm 7.4^{\mathrm{ab}}$ & $30.3 \pm 9.3^{\mathrm{ab}}$ & $39.2 \pm 5.5^{\mathrm{ab}}$ & $40.7 \pm 9.8^{\mathrm{a}}$ & $56.5 \pm 13.9^{\mathrm{a}}$ & $70.8 \pm 33.6^{\mathrm{ab}}$ \\
\hline Luvisol & Day 1 & Day 2 & Day 3 & Day 4 & Day 7 & Day 14 & Day 21 \\
\hline Control & $27.0 \pm 1.0^{\mathrm{a}}$ & $30.3 \pm 1.0^{\mathrm{a}}$ & $33.6 \pm 3.6^{\mathrm{a}}$ & $55.9 \pm 1.0^{\mathrm{a}}$ & $50.8 \pm 9.3^{\mathrm{a}}$ & $64.2 \pm 14.0^{\mathrm{a}}$ & $34.7 \pm 7.8^{\mathrm{a}}$ \\
\hline Control $+\mathrm{Hg}$ & $43.6 \pm 0.8^{\mathrm{abc}}$ & $43.3 \pm 10.1^{\mathrm{ab}}$ & $45.1 \pm 7.0^{\mathrm{abc}}$ & $67.4 \pm 5.1^{\mathrm{ab}}$ & $61.5 \pm 6.7^{\mathrm{a}}$ & $77.4 \pm 8.5^{\mathrm{ab}}$ & $37.8 \pm 7.1^{\mathrm{a}}$ \\
\hline Digestate & $161 \pm 9^{d}$ & $142 \pm 23^{\mathrm{d}}$ & $169 \pm 8^{\mathrm{d}}$ & $191 \pm 2^{c}$ & $198 \pm 25^{\mathrm{c}}$ & $189 \pm 19^{c}$ & $301 \pm 30^{c}$ \\
\hline Digestate $+\mathrm{Hg}$ & $148 \pm 9^{\mathrm{d}}$ & $176 \pm 2^{\mathrm{e}}$ & $180 \pm 5^{\mathrm{d}}$ & $222 \pm 10^{\mathrm{d}}$ & $223 \pm 11^{c}$ & $229 \pm 11^{\mathrm{d}}$ & $266 \pm 81^{c}$ \\
\hline Ash & $54.9 \pm 10.4^{\mathrm{c}}$ & $59.4 \pm 8.8^{\mathrm{b}}$ & $53.2 \pm 9.0^{\mathrm{bc}}$ & $87.0 \pm 14.2^{\mathrm{b}}$ & $131.4 \pm 42.3^{\mathrm{b}}$ & $114.0 \pm 23.8^{\mathrm{b}}$ & $101.5 \pm 34.1^{\mathrm{b}}$ \\
\hline $\mathrm{Ash}+\mathrm{Hg}$ & $54.4 \pm 7.2^{\mathrm{c}}$ & $58.6 \pm 2.4^{\mathrm{b}}$ & $58.9 \pm 4.8^{c}$ & $86.0 \pm 12.1^{\mathrm{b}}$ & $81.9 \pm 5.8^{\mathrm{ab}}$ & $108.9 \pm 0.8^{\mathrm{b}}$ & $83.0 \pm 69.1^{a}$ \\
\hline$\left(\mathrm{NH}_{4}\right)_{2} \mathrm{SO}_{4}$ & $27.9 \pm 0.5^{\mathrm{ab}}$ & $28.5 \pm 1.5^{\mathrm{a}}$ & $29.0 \pm 1.7^{\mathrm{a}}$ & $50.3 \pm 8.3^{\mathrm{a}}$ & $42.8 \pm 6.6^{\mathrm{a}}$ & $60.9 \pm 12.4^{\mathrm{a}}$ & $125.6 \pm 3.2^{\mathrm{b}}$ \\
\hline$\left(\mathrm{NH}_{4}\right)_{2} \mathrm{SO}_{4}+\mathrm{Hg}$ & $46.5 \pm 4.6^{\mathrm{bc}}$ & $46.9 \pm 5.2^{\mathrm{ab}}$ & $42.6 \pm 3.2^{\mathrm{ab}}$ & $62.4 \pm 12.4^{\mathrm{ab}}$ & $65.9 \pm 6.0^{\mathrm{a}}$ & $63.6 \pm 2.9^{\mathrm{a}}$ & $70.8 \pm 5.2^{\mathrm{a}}$ \\
\hline
\end{tabular}

On the contrary, the extremely high $\mathrm{Zn}$ level in the ash (Table 2) resulted in the significant increase in the extractable $\mathrm{Zn}$ portion of the ash-treated soil regardless of the soil type (Table 11). A similar pattern was reported for $\mathrm{Mg}$, where the increase in the extractable $\mathrm{Mg}$ portion was more apparent in Luvisol (Table 4). Whereas in the Luvisol the mobile Mg contents increased twice after ash application, the mobile portion of $\mathrm{Mg}$ in Chernozem rised only by $10-15 \%$. The low mobility of micronutrients in various ash samples was also confirmed by Száková et al. [41]. The K, Mn, and P extractable levels tended to increase compared to controls (significance of the differences at $P<0.05$ was unambiguously proved only in the case of $\mathrm{Mn}$, see Table 8) but were significantly lower compared to digestate application, not confirming the high $\mathrm{K}$ leachability from ash samples observed by Steenari et al. [40]. Although the total S contents added via the individual treatments were comparable, the mobile portions of ashderived S were lower compared to those after the application of digestate and ammonium sulfate. Ochecová et al. [20] observed increasing mobile portions of $\mathrm{Ca}, \mathrm{P}, \mathrm{K}, \mathrm{Mg}$, and $\mathrm{Mn}$ in the fly ash-treated soil after a 3-year model pot experiment. However, the effects were significant for the 3-6 fold higher 
TABLE 9: The concentrations of $\mathrm{P}$ extractable with $0.11 \mathrm{~mol} \mathrm{~L}-1$ acetic acid within the incubation experiment $\left(\mathrm{mg} \cdot \mathrm{kg}^{-1}\right)$; the averages marked by the same letter did not significantly differ at $P<0.05$ within individual columns; data are presented as mean \pm standard deviation $(n=3)$.

\begin{tabular}{|c|c|c|c|c|c|c|c|}
\hline Chernozem & Day 1 & Day 2 & Day 3 & Day 4 & Day 7 & Day 14 & Day 21 \\
\hline Control & $90.9 \pm 6.3^{\mathrm{a}}$ & $88.9 \pm 24.9^{\mathrm{a}}$ & $112.3 \pm 33.3^{\mathrm{a}}$ & $109.3 \pm 7.0^{\mathrm{a}}$ & $93.6 \pm 7.9^{\mathrm{a}}$ & $88.8 \pm 11.7^{\mathrm{a}}$ & $55.9 \pm 6.5^{\mathrm{a}}$ \\
\hline Control $+\mathrm{Hg}$ & $85.0 \pm 17.9^{\mathrm{a}}$ & $88.1 \pm 1.9^{\mathrm{a}}$ & $108.4 \pm 19.0^{\mathrm{a}}$ & $127.8 \pm 14.3^{\mathrm{a}}$ & $91.2 \pm 4.7^{\mathrm{a}}$ & $98.1 \pm 14.1^{\mathrm{a}}$ & $79.3 \pm 13.9^{\mathrm{a}}$ \\
\hline Digestate & $259.0 \pm 50.0^{\mathrm{b}}$ & $269.0 \pm 49.5^{\mathrm{b}}$ & $235.2 \pm 63.2^{\mathrm{b}}$ & $320.9 \pm 60.5^{b}$ & $189.1 \pm 23.5^{\mathrm{b}}$ & $278.6 \pm 30.5^{\mathrm{b}}$ & $246.0 \pm 59.9^{b}$ \\
\hline Digestate + Hg & $250.9 \pm 62.4^{\mathrm{b}}$ & $285.6 \pm 28.3^{\mathrm{b}}$ & $261.6 \pm 40.4^{\mathrm{b}}$ & $361.0 \pm 14.2^{\mathrm{b}}$ & $293.6 \pm 12.5^{\mathrm{c}}$ & $274.5 \pm 51.7^{\mathrm{b}}$ & $253.5 \pm 51.8^{\mathrm{b}}$ \\
\hline Ash & $107.1 \pm 6.2^{\mathrm{a}}$ & $102.1 \pm 17.1^{\mathrm{a}}$ & $101.7 \pm 2.9^{\mathrm{a}}$ & $130.0 \pm 18.1^{\mathrm{a}}$ & $115.4 \pm 17.5^{\mathrm{a}}$ & $98.9 \pm 9.2^{\mathrm{a}}$ & $123.3 \pm 30.4^{\mathrm{a}}$ \\
\hline $\mathrm{Ash}+\mathrm{Hg}$ & $104.2 \pm 7.5^{\mathrm{a}}$ & $101.6 \pm 5.7^{\mathrm{a}}$ & $105.5 \pm 6.4^{\mathrm{a}}$ & $138.3 \pm 11.9^{\mathrm{a}}$ & $118.4 \pm 28.0^{\mathrm{a}}$ & $115.3 \pm 6.0^{\mathrm{a}}$ & $96.6 \pm 19.6^{\mathrm{a}}$ \\
\hline$\left(\mathrm{NH}_{4}\right)_{2} \mathrm{SO}_{4}$ & $96.9 \pm 10.0^{\mathrm{a}}$ & $91.3 \pm 1.7^{\mathrm{a}}$ & $93.4 \pm 13.1^{\mathrm{a}}$ & $110.4 \pm 4.8^{\mathrm{a}}$ & $94.4 \pm 1.2^{\mathrm{a}}$ & $102.2 \pm 12.6^{\mathrm{a}}$ & $116.8 \pm 15.6^{\mathrm{a}}$ \\
\hline$\left(\mathrm{NH}_{4}\right)_{2} \mathrm{SO}_{4}+\mathrm{Hg}$ & $84.3 \pm 4.7^{\mathrm{a}}$ & $90.2 \pm 4.3^{\mathrm{a}}$ & $117.9 \pm 22.3^{\mathrm{a}}$ & $118.7 \pm 17.1^{\mathrm{a}}$ & $95.4 \pm 3.1^{\mathrm{a}}$ & $91.8 \pm 7.9^{\mathrm{a}}$ & $106.5 \pm 37.4^{\mathrm{a}}$ \\
\hline Luvisol & Day 1 & Day 2 & Day 3 & Day 4 & Day 7 & Day 14 & Day 21 \\
\hline Control & $62.9 \pm 5.8^{\mathrm{a}}$ & $61.9 \pm 6.3^{\mathrm{a}}$ & $61.2 \pm 11.1^{\mathrm{a}}$ & $70.8 \pm 0.6^{\mathrm{a}}$ & $65.8 \pm 16.3^{\mathrm{a}}$ & $56.62 .7 \pm^{\mathrm{a}}$ & $38.9 \pm 3.8^{\mathrm{a}}$ \\
\hline Control $+\mathrm{Hg}$ & $66.8 \pm 9.6^{\mathrm{a}}$ & $63.4 \pm 0.5^{\mathrm{a}}$ & $65.6 \pm 10.4^{\mathrm{a}}$ & $71.5 \pm 8.6^{\mathrm{a}}$ & $62.3 \pm 1.7^{\mathrm{a}}$ & $67.4 \pm 5.7^{\mathrm{a}}$ & $43.7 \pm 12.0^{\mathrm{a}}$ \\
\hline Digestate & $323.7 \pm 26.2^{\mathrm{b}}$ & $210.2 \pm 67.6^{\mathrm{b}}$ & $203.4 \pm 58.7^{\mathrm{b}}$ & $323.4 \pm 14.3^{\mathrm{b}}$ & $290.3 \pm 30.1^{\mathrm{b}}$ & $245.8 \pm 56.8^{\mathrm{b}}$ & $254.0 \pm 24.0^{\mathrm{c}}$ \\
\hline Digestate $+\mathrm{Hg}$ & $329.6 \pm 82.9^{\mathrm{b}}$ & $286.5 \pm 40.6^{\mathrm{b}}$ & $246.3 \pm 77.2^{b}$ & $350.0 \pm 44.8^{\mathrm{b}}$ & $348.6 \pm 90.4^{\mathrm{b}}$ & $262.2 \pm 28.7^{\mathrm{b}}$ & $130.7 \pm 48.9^{\mathrm{b}}$ \\
\hline Ash & $85.0 \pm 5.3^{\mathrm{a}}$ & $84.4 \pm 8.8^{\mathrm{a}}$ & $80.5 \pm 13.1^{\mathrm{a}}$ & $90.6 \pm 14.1^{\mathrm{a}}$ & $92.6 \pm 7.4^{\mathrm{a}}$ & $78.3 \pm 4.8^{\mathrm{a}}$ & $55.6 \pm 6.0^{\mathrm{a}}$ \\
\hline $\mathrm{Ash}+\mathrm{Hg}$ & $76.4 \pm 6.3^{\mathrm{a}}$ & $73.7 \pm 4.7^{\mathrm{a}}$ & $75.8 \pm 3.6^{\mathrm{a}}$ & $90.7 \pm 12.4^{\mathrm{a}}$ & $81.4 \pm 2.5^{\mathrm{a}}$ & $86.5 \pm 4.0^{\mathrm{a}}$ & $68.7 \pm 1.6^{\mathrm{a}}$ \\
\hline$\left(\mathrm{NH}_{4}\right)_{2} \mathrm{SO}_{4}$ & $61.3 \pm 1.1^{\mathrm{a}}$ & $58.3 \pm 3.6^{\mathrm{a}}$ & $57.3 \pm 4.0^{\mathrm{a}}$ & $69.1 \pm 8.2^{\mathrm{a}}$ & $59.4 \pm 4.8^{\mathrm{a}}$ & $59.3 \pm 4.2^{\mathrm{a}}$ & $60.6 \pm 9.2^{\mathrm{a}}$ \\
\hline$\left(\mathrm{NH}_{4}\right)_{2} \mathrm{SO}_{4}+\mathrm{Hg}$ & $60.4 \pm 1.6^{\mathrm{a}}$ & $72.9 \pm 13.7^{\mathrm{a}}$ & $59.6 \pm 2.8^{\mathrm{a}}$ & $69.5 \pm 1.2^{\mathrm{a}}$ & $63.3 \pm 4.1^{\mathrm{a}}$ & $58.8 \pm 2.5^{\mathrm{a}}$ & $58.7 \pm 0.6^{\mathrm{a}}$ \\
\hline
\end{tabular}

TABLE 10: The concentrations of S extractable with $0.11 \mathrm{~mol} \mathrm{~L}^{-1}$ acetic acid within the incubation experiment $\left(\mathrm{mg} \cdot \mathrm{kg}^{-1}\right)$; the averages marked by the same letter did not significantly differ at $P<0.05$ within individual columns; data are presented as mean \pm standard deviation $(n=3)$.

\begin{tabular}{|c|c|c|c|c|c|c|c|}
\hline Chernozem & Day 1 & Day 2 & Day 3 & Day 4 & Day 7 & Day 14 & Day 21 \\
\hline Control & $8.8 \pm 1.0^{\mathrm{a}}$ & $9.7 \pm 0.9^{\mathrm{a}}$ & $12.3 \pm 5.6^{\mathrm{a}}$ & $14.9 \pm 5.0^{\mathrm{a}}$ & $17.7 \pm 2.1^{\mathrm{a}}$ & $16.1 \pm 4.1^{\mathrm{a}}$ & $10.0 \pm 2.7^{\mathrm{a}}$ \\
\hline Control $+\mathrm{Hg}$ & $9.3 \pm 0.6^{\mathrm{a}}$ & $9.6 \pm 0.6^{\mathrm{a}}$ & $9.6 \pm 1.5^{\mathrm{a}}$ & $13.0 \pm 2.4^{\mathrm{a}}$ & $15.1 \pm 4.3^{\mathrm{a}}$ & $15.2 \pm 3.7^{\mathrm{a}}$ & $15.5 \pm 4.6^{\mathrm{a}}$ \\
\hline Digestate & $255.0 \pm 114.1^{\mathrm{bc}}$ & $199.5 \pm 54.8^{\mathrm{b}}$ & $129.0 \pm 31.7^{\mathrm{b}}$ & $89.7 \pm 21.3^{\mathrm{ab}}$ & $66.1 \pm 3.5^{\mathrm{ab}}$ & $132.2 \pm 52.9^{\mathrm{ab}}$ & $211.3 \pm 93.9^{b c}$ \\
\hline Digestate $+\mathrm{Hg}$ & $141.4 \pm 30.4^{\mathrm{b}}$ & $221.6 \pm 29.6^{b}$ & $162.7 \pm 46.2^{\mathrm{b}}$ & $198.1 \pm 63.6^{\mathrm{ab}}$ & $91.6 \pm 6.7^{\mathrm{ab}}$ & $136.4 \pm 49.1^{\mathrm{ab}}$ & $307.6 \pm 110.8^{\mathrm{cd}}$ \\
\hline Ash & $138.1 \pm 37.6^{\mathrm{b}}$ & $140.8 \pm 32.9^{b}$ & $143.9 \pm 33.0^{b}$ & $153.8 \pm 37.3^{\mathrm{ab}}$ & $168.1 \pm 12.0^{\mathrm{b}}$ & $165.4 \pm 16.1^{\mathrm{ab}}$ & $201.9 \pm 62.7^{\mathrm{bc}}$ \\
\hline $\mathrm{Ash}+\mathrm{Hg}$ & $138.2 \pm 20.2^{\mathrm{b}}$ & $158.9 \pm 7.5^{\mathrm{b}}$ & $155.2 \pm 21.9^{b}$ & $243.6 \pm 41.8^{\mathrm{ab}}$ & $192.6 \pm 3.3^{\mathrm{b}}$ & $205.0 \pm 28.7^{\mathrm{b}}$ & $202.5 \pm 54.7^{\mathrm{bc}}$ \\
\hline$\left(\mathrm{NH}_{4}\right)_{2} \mathrm{SO}_{4}$ & $344.0 \pm 82.0^{c}$ & $494.3 \pm 153.6^{c}$ & $454.5 \pm 79.6^{c}$ & $602.6 \pm 145.5^{c}$ & $483.6 \pm 55.2^{\mathrm{c}}$ & $528.4 \pm 91.7^{\mathrm{c}}$ & $519.6 \pm 104.6^{\mathrm{e}}$ \\
\hline$\left(\mathrm{NH}_{4}\right)_{2} \mathrm{SO}_{4}+\mathrm{Hg}$ & $366.3 \pm 66.7^{\mathrm{c}}$ & $445.8 \pm 94.6^{c}$ & $386.7 \pm 13.1^{c}$ & $660.6 \pm 189.3^{c}$ & $483.2 \pm 162.3^{c}$ & $766.5 \pm 78.7^{\mathrm{d}}$ & $429.7 \pm 123.6^{\mathrm{de}}$ \\
\hline Luvisol & Day 1 & Day 2 & Day 3 & Day 4 & Day 7 & Day 14 & Day 21 \\
\hline Control & $4.6 \pm 1.0^{\mathrm{a}}$ & $4.9 \pm 1.0^{\mathrm{a}}$ & $5.3 \pm 1.1^{\mathrm{a}}$ & $8.6 \pm 2.3^{\mathrm{a}}$ & $11.1 \pm 3.6^{\mathrm{a}}$ & $11.8 \pm 6.3^{\mathrm{a}}$ & $9.2 \pm 3.3^{\mathrm{a}}$ \\
\hline Control $+\mathrm{Hg}$ & $5.0 \pm 1.0^{\mathrm{a}}$ & $4.7 \pm 0.3^{\mathrm{a}}$ & $5.7 \pm 0.4^{\mathrm{a}}$ & $9.8 \pm 6.1^{\mathrm{a}}$ & $11.4 \pm 5.5^{\mathrm{a}}$ & $10.2 \pm 4.9^{\mathrm{a}}$ & $7.0 \pm 0.6^{\mathrm{a}}$ \\
\hline Digestate & $296.4 \pm 27.4^{b c}$ & $221.6 \pm 27.5^{b c}$ & $275.5 \pm 32.2^{b c}$ & $420.5 \pm 122.4^{\mathrm{cd}}$ & $329.1 \pm 62.0^{\mathrm{cd}}$ & $220.3 \pm 121.1^{\mathrm{b}}$ & $264.9 \pm 101.4^{\mathrm{b}}$ \\
\hline Digestate $+\mathrm{Hg}$ & $273.2 \pm 55.6^{\mathrm{bc}}$ & $205.9 \pm 19.7^{\mathrm{bc}}$ & $234.2 \pm 46.2^{\mathrm{bc}}$ & $229.7 \pm 48.9^{\mathrm{bc}}$ & $80.3 \pm 26.6^{\mathrm{ab}}$ & $94.9 \pm 11.1 \mathrm{a}^{\mathrm{b}}$ & $362.5 \pm 93.2^{\mathrm{b}}$ \\
\hline Ash & $183.2 \pm 75.2^{\mathrm{b}}$ & $183.2 \pm 20.0^{\mathrm{b}}$ & $214.5 \pm 64.0^{\mathrm{b}}$ & $208.2 \pm 15.6^{\mathrm{b}}$ & $223.6 \pm 13.8^{b c}$ & $198.3 \pm 14.0^{\mathrm{b}}$ & $151.0 \pm 27.1^{\mathrm{b}}$ \\
\hline $\mathrm{Ash}+\mathrm{Hg}$ & $134.5 \pm 21.6^{\mathrm{b}}$ & $131.6 \pm 11.8^{\mathrm{b}}$ & $152.8 \pm 21.2^{\mathrm{b}}$ & $219.1 \pm 27.2^{\mathrm{bc}}$ & $233.4 \pm 34.5^{\mathrm{bc}}$ & $228.7 \pm 40.6^{\mathrm{b}}$ & $203.4 \pm 36.8^{\mathrm{b}}$ \\
\hline$\left(\mathrm{NH}_{4}\right)_{2} \mathrm{SO}_{4}$ & $443.5 \pm 96.3^{c}$ & $403.0 \pm 96.0^{c}$ & $466.6 \pm 87.8^{c}$ & $590.4 \pm 130.9^{\mathrm{d}}$ & $430.3 \pm 97.5^{\mathrm{d}}$ & $505.2 \pm 108.6^{\mathrm{c}}$ & $570.8 \pm 118.5^{\mathrm{c}}$ \\
\hline$\left(\mathrm{NH}_{4}\right)_{2} \mathrm{SO}_{4}+\mathrm{Hg}$ & $536.1 \pm 61.6^{c}$ & $564.1 \pm 30.2^{c}$ & $541.0 \pm 78.0^{c}$ & $687.8 \pm 87.9^{\mathrm{e}}$ & $560.1 \pm 24.8^{\mathrm{e}}$ & $564.4 \pm 72.6^{c}$ & $701.8 \pm 31.8^{c}$ \\
\hline
\end{tabular}

ash rate compared to our experiment. Thus, the increase of mobile nutrient contents in soils will manifest at higher ash rates compared to our experiment.

The interrelationships between soil $\mathrm{Hg}$ and other soil element contents described by Reis et al. [14] indicate that the presence of $\mathrm{Hg}$ in the mobile phase could be related to $\mathrm{Mn}$ and $\mathrm{Al}$ soil contents. Furthermore, an antagonistic effect of $\mathrm{Mn}$ against $\mathrm{Hg}$ is suggested. Our data tended to increase of mobile Mn contents during the incubation (Table 8) as related to decreasing mobile Hg (Figure 1). Similarly, Sierra et al.
[42] observed negative significant correlation between the available $\mathrm{Mn}$ in the rhizosphere and $\mathrm{Hg}$ content in plants. On the contrary, $\mathrm{S}$ content contributed to $\mathrm{Hg}$ retention in the soil matrix, reducing the mobility of the metal [14]. In our case, the changes of $\mathrm{Hg}$ mobility in soils (Figure 1) did not reflect the changes in mobile portion of $\mathrm{S}$ during the incubation experiment (Table 10). In contrast, the presence of sulfates seems to favor $\mathrm{Hg}$ uptake by the plant. There was a positive significant correlation between the sulfate concentration in the rhizosphere and the $\mathrm{Hg}$ within the 
TABLE 11: The concentrations of $\mathrm{Zn}$ extractable with $0.11 \mathrm{~mol} \mathrm{~L}^{-1}$ acetic acid within the incubation experiment $\left(\mathrm{mg} \cdot \mathrm{kg}^{-1}\right)$; the averages marked by the same letter did not significantly differ at $P<0.05$ within individual columns; data are presented as mean \pm standard deviation $(n=3)$.

\begin{tabular}{|c|c|c|c|c|c|c|c|}
\hline Chernozem & Day 1 & Day 2 & Day 3 & Day 4 & Day 7 & Day 14 & Day 21 \\
\hline Control & $1.34 \pm 0.07^{\mathrm{a}}$ & $1.37 \pm 0.08^{\mathrm{a}}$ & $0.87 \pm 0.03^{\mathrm{a}}$ & $1.57 \pm 0.19^{\mathrm{a}}$ & $1.42 \pm 0.40^{\mathrm{a}}$ & $1.32 \pm 0.26^{\mathrm{a}}$ & $0.59 \pm 0.02^{\mathrm{a}}$ \\
\hline Control + Hg & $1.43 \pm 0.29^{\mathrm{a}}$ & $1.27 \pm 0.06^{\mathrm{a}}$ & $0.88 \pm 0.15^{\mathrm{a}}$ & $1.36 \pm 0.19^{\mathrm{a}}$ & $1.28 \pm 0.08^{\mathrm{a}}$ & $1.28 \pm 0.16^{\mathrm{a}}$ & $0.97 \pm 0.33^{\mathrm{a}}$ \\
\hline Digestate & $6.56 \pm 0.81^{\mathrm{a}}$ & $6.69 \pm 1.21^{\mathrm{a}}$ & $6.02 \pm 1.11^{\mathrm{a}}$ & $9.02 \pm 0.93^{\mathrm{a}}$ & $7.44 \pm 0.26^{\mathrm{a}}$ & $11.06 \pm 1.22^{\mathrm{a}}$ & $12.51 \pm 1.37^{\mathrm{a}}$ \\
\hline Digestate $+\mathrm{Hg}$ & $5.23 \pm 1.36^{\mathrm{a}}$ & $5.74 \pm 0.82^{\mathrm{a}}$ & $5.21 \pm 0.84^{\mathrm{a}}$ & $7.76 \pm 0.34^{\mathrm{a}}$ & $6.69 \pm 0.26^{\mathrm{a}}$ & $7.89 \pm 0.17^{\mathrm{a}}$ & $9.98 \pm 1.51^{\mathrm{a}}$ \\
\hline Ash & $109.3 \pm 23.2^{\mathrm{b}}$ & $52.1 \pm 20.0^{b}$ & $85.8 \pm 21.8^{\mathrm{b}}$ & $93.9 \pm 23.7^{b}$ & $102.9 \pm 12.2^{\mathrm{b}}$ & $77.2 \pm 17.3^{b}$ & $126.6 \pm 32.9^{\mathrm{b}}$ \\
\hline $\mathrm{Ash}+\mathrm{Hg}$ & $52.6 \pm 25.8^{\mathrm{b}}$ & $47.1 \pm 10.4^{\mathrm{b}}$ & $81.5 \pm 21.4^{\mathrm{b}}$ & $153.8 \pm 25.7^{\mathrm{C}}$ & $108.5 \pm 31.6^{\mathrm{b}}$ & $137.6 \pm 22.4^{\mathrm{c}}$ & $154.3 \pm 28.8^{\mathrm{b}}$ \\
\hline$\left(\mathrm{NH}_{4}\right)_{2} \mathrm{SO}_{4}$ & $1.57 \pm 0.29^{\mathrm{a}}$ & $1.55 \pm 0.15^{\mathrm{a}}$ & $1.12 \pm 0.09^{\mathrm{a}}$ & $1.67 \pm 0.07^{\mathrm{a}}$ & $1.66 \pm 0.20^{\mathrm{a}}$ & $2.29 \pm 0.27^{\mathrm{a}}$ & $2.27 \pm 0.32^{\mathrm{a}}$ \\
\hline$\left(\mathrm{NH}_{4}\right)_{2} \mathrm{SO}_{4}+\mathrm{Hg}$ & $1.65 \pm 0.26^{\mathrm{a}}$ & $1.39 \pm 0.08^{\mathrm{a}}$ & $1.15 \pm 0.18^{\mathrm{a}}$ & $1.44 \pm 0.13^{\mathrm{a}}$ & $1.45 \pm 0.13^{\mathrm{a}}$ & $1.56 \pm 0.06^{\mathrm{a}}$ & $5.02 \pm 0.35^{\mathrm{a}}$ \\
\hline Luvisol & Day 1 & Day 2 & Day 3 & Day 4 & Day 7 & Day 14 & Day 21 \\
\hline Control & $2.66 \pm 0.10^{\mathrm{a}}$ & $2.92 \pm 0.19^{\mathrm{a}}$ & $2.46 \pm 0.21^{\mathrm{a}}$ & $3.45 \pm 0.19^{\mathrm{a}}$ & $3.21 \pm 0.12^{\mathrm{a}}$ & $3.15 \pm 0.10^{\mathrm{a}}$ & $2.02 \pm 0.39^{\mathrm{a}}$ \\
\hline Control $+\mathrm{Hg}$ & $2.94 \pm 0.06^{\mathrm{a}}$ & $2.99 \pm 0.30^{\mathrm{a}}$ & $2.64 \pm 0.15^{\mathrm{a}}$ & $4.84 \pm 2.17^{\mathrm{a}}$ & $3.05 \pm 0.04^{\mathrm{a}}$ & $3.26 \pm 0.06^{\mathrm{a}}$ & $2.41 \pm 0.89^{\mathrm{a}}$ \\
\hline Digestate & $11.58 \pm 0.67^{\mathrm{a}}$ & $8.13 \pm 2.02^{\mathrm{a}}$ & $8.53 \pm 1.57^{\mathrm{a}}$ & $14.04 \pm 0.43^{\mathrm{a}}$ & $13.07 \pm 0.99^{\mathrm{a}}$ & $12.49 \pm 1.14^{\mathrm{a}}$ & $14.68 \pm 1.98^{\mathrm{a}}$ \\
\hline Digestate $+\mathrm{Hg}$ & $9.02 \pm 1.29^{\mathrm{a}}$ & $8.33 \pm 1.04^{\mathrm{a}}$ & $7.86 \pm 0.69^{\mathrm{a}}$ & $10.24 \pm 0.52^{\mathrm{a}}$ & $9.98 \pm 0.73^{\mathrm{a}}$ & $11.85 \pm 1.90^{\mathrm{a}}$ & $6.81 \pm 4.38^{\mathrm{a}}$ \\
\hline Ash & $181.6 \pm 30.7^{\mathrm{b}}$ & $172.9 \pm 28.8^{b}$ & $161.4 \pm 32.8^{\mathrm{b}}$ & $164.6 \pm 31.0^{\mathrm{b}}$ & $214.2 \pm 24.5^{\mathrm{c}}$ & $155.6 \pm 25.8^{\mathrm{b}}$ & $115.8 \pm 23.0^{\mathrm{b}}$ \\
\hline $\mathrm{Ash}+\mathrm{Hg}$ & $112.4 \pm 31.8^{\mathrm{b}}$ & $92.2 \pm 12.3^{\mathrm{b}}$ & $121.1 \pm 23.3^{b}$ & $165.8 \pm 34.6^{\mathrm{b}}$ & $162.6 \pm 4.6^{\mathrm{b}}$ & $201.9 \pm 35.7^{\mathrm{b}}$ & $230.9 \pm 38.7^{\mathrm{c}}$ \\
\hline$\left(\mathrm{NH}_{4}\right)_{2} \mathrm{SO}_{4}$ & $3.05 \pm 0.18^{\mathrm{a}}$ & $3.16 \pm 0.73^{\mathrm{a}}$ & $2.65 \pm 0.04^{\mathrm{a}}$ & $3.74 \pm 0.21^{\mathrm{a}}$ & $3.38 \pm 0.13^{\mathrm{a}}$ & $3.98 \pm 0.50^{\mathrm{a}}$ & $4.39 \pm 1.42^{\mathrm{a}}$ \\
\hline$\left(\mathrm{NH}_{4}\right)_{2} \mathrm{SO}_{4}+\mathrm{Hg}$ & $3.37 \pm 0.24^{\mathrm{a}}$ & $3.17 \pm 0.28^{\mathrm{a}}$ & $2.95 \pm 0.24^{\mathrm{a}}$ & $4.18 \pm 0.08^{\mathrm{a}}$ & $3.18 \pm 0.31^{\mathrm{a}}$ & $3.44 \pm 0.07^{\mathrm{a}}$ & $3.46 \pm 0.35^{\mathrm{a}}$ \\
\hline
\end{tabular}

aerial and root parts of plants [42]. However, only total $\mathrm{S}$ extracted with the $0.11 \mathrm{~mol} \mathrm{~L}^{-1}$ solution of $\mathrm{CH}_{3} \mathrm{COOH}$ was determined by the ICP-OES and a portion of mobile sulfates in the extract was not determined in our case and requires further research. The competition between $\mathrm{Hg}$ and $\mathrm{Cu}$ and $\mathrm{Hg}$ and $\mathrm{Zn}$ in soils described by Jing et al. [19] was not confirmed in our case. For Fe, Mehrotra and Sedlak [43] and Rhoton and Bennett [44] highlighted Hg immobilization via sorption and/or the complexation of $\mathrm{Hg}$ with $\mathrm{Fe}$ compounds in soil. This statement seems to be confirmed for Chernozem, whereas the opposite pattern was observed in Luvisol. In Chernozem, the mobile portions of Fe decreased significantly after digestate application on the $\mathrm{Hg}$ amended samples compared to the unamended ones. In Luvisol, the mobile Fe contents increased in the $\mathrm{Hg}+$ digestate amended samples since 2 nd day of incubation with maximum at 7 th day suggesting competitive relationships of $\mathrm{Fe}$ and $\mathrm{Hg}$ in this case. The complexity of $\mathrm{Hg}$ sorption on $\mathrm{Fe} / \mathrm{Mn}$ oxides was documented by Liang et al. [45], where the role of amorphous/crystalline $\mathrm{Fe}$ and $\mathrm{Mn}$ hydroxides, humic acids content, and also chlorine concentrations were mentioned. Šípková et al. [46] observed a negative correlation between $\mathrm{Hg}$ content bound to the humic acids and the content of $\mathrm{Mg}, \mathrm{Mn}$, and Fe. Therefore, the more detailed information concerning soil components, humic acid portions in the digestate, as well as the importance of the application of $\mathrm{HgCl}_{2}$ compared to the other $\mathrm{Hg}$ compounds remains to be elucidated in further research.

\section{Conclusions}

Although the response of $\mathrm{Hg}$ contaminated soils in different ameliorative materials was affected by the individual parameters of the soils, especially by the different soil sorption capacity and organic matter contents in these soils, digestate proved to be the most effective for the immobilization of $\mathrm{Hg}$ in soil. Contrary to the other S-bearing measures such as wood fly ash and ammonium sulfate, in the case of digestate, the $\mathrm{Hg}$ immobilizing effectiveness resulted from the cooperation of various factors such as $\mathrm{S}$ and organic matter content. Moreover, the digestate application can result in an improvement in the macro- and micronutrient status of the soil, where mobile and theoretically plant-available portions of these elements increased in particular. Thus, the field application of organic matter-rich biowaste such as digestate seems to be reasonable for the disposal of this type of material, leading to a decreased environmental risk of $\mathrm{Hg}$ contamination in soil.

\section{Conflict of Interests}

The authors declared that there is no conflict of interests.

\section{Acknowledgments}

Authors are thankful for financial support of the GAČR Project P503/12/0682, ESF and MŠMT Project no. CZ.1.07/ 2.3.00/30.0040, and Czech University of Life Science Project no. 21140/1313/3130; correction and improvement of language was provided by Proof-Reading-Service.com Ltd., Devonshire Business Centre, Works Road, Letchworth Garden City SG6 1GJ, United Kingdom.

\section{References}

[1] EPA, Mercury Study Report to Congress, vol. 1 of Executive Summary, EPA-452/R-97-003, GPO, Washington, DC, USA, 1997. 
[2] E. Tipping, S. Lofts, H. Hooper, B. Frey, D. Spurgeon, and C. Svendsen, "Critical Limits for $\mathrm{Hg}$ (II) in soils, derived from chronic toxicity data," Environmental Pollution, vol. 158, no. 7, pp. 2465-2471, 2010.

[3] J. Li, Y. Lu, H. Shim et al., "Use of the BCR sequential extraction procedure for the study of metal availability to plants," Journal of Environmental Monitoring, vol. 12, no. 2, pp. 466-471, 2010.

[4] S. M. Rodrigues, B. Henriques, J. Coimbra, E. F. da Silva, M. E. Pereira, and A. C. Duarte, "Water-soluble fraction of mercury, arsenic and other potentially toxic elements in highly contaminated sediments and soils," Chemosphere, vol. 78, no. 11, pp. 1301-1312, 2010.

[5] L. Boszke, A. Kowalski, A. Astel, A. Barański, B. Gworek, and J. Siepak, "Mercury mobility and bioavailability in soil from contaminated area," Environmental Geology, vol. 55, no. 5, pp. 1075-1087, 2008.

[6] W. Luo, Y. Lu, B. Wang et al., "Distribution and sources of mercury in soils from former industrialized urban areas of Beijing, China," Environmental Monitoring and Assessment, vol. 158, no. 1-4, pp. 507-517, 2009.

[7] A. Hassen, N. Saidi, M. Cherif, and A. Boudabous, "Resistance of environmental bacteria to heavy metals," Bioresource Technology, vol. 64, no. 1, pp. 7-15, 1998.

[8] A. R. Khwaja, P. R. Bloom, and P. L. Brezonik, "Binding constants of divalent mercury $\left(\mathrm{Hg}^{2+}\right)$ in soil humic acids and soil organic matter," Environmental Science \& Technology, vol. 40, no. 3, pp. 844-849, 2006.

[9] D. A. Heeraman, V. P. Claassen, and R. J. Zasoski, "Interaction of lime, organic matter and fertilizer on growth and uptake of arsenic and mercury by Zorro fescue (Vulpia myuros L.)," Plant and Soil, vol. 234, no. 2, pp. 215-231, 2001.

[10] M. Linde, I. Öborn, and J. P. Gustafsson, "Effects of changed soil conditions on the mobility of trace metals in moderately contaminated urban soils," Water, Air, and Soil Pollution, vol. 183, no. 1-4, pp. 69-83, 2007.

[11] A. Yao, R. Qiu, C. Qing, S. Mu, and E. J. Reardon, "Effects of humus on the environmental activity of mineral-bound Hg: influence on Hg plant uptake," Journal of Soils and Sediments, vol. 11, no. 6, pp. 959-967, 2011.

[12] Y. Yang, L. Liang, and D. Wang, "Effect of dissolved organic matter on adsorption and desorption of mercury by soils," Journal of Environmental Sciences, vol. 20, no. 9, pp. 1097-1102, 2008.

[13] G. J. Zagury, C.-M. Neculita, C. Bastien, and L. Deschênes, "Mercury fractionation, bioavailability, and ecotoxicity in highly contaminated soils from chlor-alkali plants," Environmental Toxicology and Chemistry, vol. 25, no. 4, pp. 1138-1147, 2006.

[14] A. T. Reis, S. M. Rodrigues, C. M. Davidson, E. Pereira, and A. C. Duarte, "Extractability and mobility of mercury from agricultural soils surrounding industrial and mining contaminated areas," Chemosphere, vol. 81, no. 11, pp. 1369-1377, 2010.

[15] M. O. Barnett, L. A. Harris, R. R. Turner et al., "Formation of mercuric sulfide in soil," Environmental Science \& Technology, vol. 31, no. 11, pp. 3037-3043, 1997.

[16] D. Hesterberg, J. W. Chou, K. J. Hutchison, and D. E. Sayers, "Bonding of HG(II) to reduced organic sulfur in humic acid as affected by S/Hg ratio," Environmental Science and Technology, vol. 35, no. 13, pp. 2741-2745, 2001.

[17] S. Remy, P. Prudent, and J.-L. Probst, "Mercury speciation in soils of the industrialised Thur River catchment (Alsace, France)," Applied Geochemistry, vol. 21, no. 11, pp. 1855-1867, 2006.
[18] S. Åkerblom, K. Bishop, E. Björn, L. Lambertsson, T. Eriksson, and M. B. Nilsson, "Significant interaction effects from sulfate deposition and climate on sulfur concentrations constitute major controls on methylmercury production in peatlands," Geochimica et Cosmochimica Acta, vol. 102, pp. 1-11, 2013.

[19] Y. D. Jing, Z. L. He, and X. E. Yang, "Effects of pH, organic acids, and competitive cations on mercury desorption in soils," Chemosphere, vol. 69, no. 10, pp. 1662-1669, 2007.

[20] P. Ochecová, P. Tlustoš, and J. Száková, "Wheat and soil response to wood fly ash application in contaminated soils," Agronomy Journal, vol. 106, no. 3, pp. 995-1002, 2014.

[21] P. Quevauviller, A. Ure, H. Muntau, and B. Griepink, "Improvement of analytical measurements within the BCR-programsingle and sequential extraction procedures applied to soil and sediment analysis," International Journal of Environmental Analytical Chemistry, vol. 51, pp. 129-134, 1993.

[22] A. Mehlich, "Mehlich 3 soil test extractant: a modification of Mehlich 2 extractant," Communications in Soil Science \& Plant Analysis, vol. 15, no. 12, pp. 1409-1416, 1984.

[23] A. Šípková, J. Száková, P. Coufalík, O. Zvěřina, L. Kacálková, and P. Tlustoš, "Mercury distribution and mobility in contaminated soils from vicinity of waste incineration plant," Plant, Soil and Environment, vol. 60, no. 2, pp. 87-92, 2014.

[24] P. Ruggiero, R. Terzano, M. Spagnuolo et al., "Hg bioavailability and impact on bacterial communities in a long-term polluted soil," Journal of Environmental Monitoring, vol. 13, no. 1, pp. 145156, 2011.

[25] B. Demirel, N. P. Göl, and T. T. Onay, "Evaluation of heavy metal content in digestate from batch anaerobic co-digestion of sunflower hulls and poultry manure," Journal of Material Cycles and Waste Management, vol. 15, no. 2, pp. 242-246, 2013.

[26] R. Pöykiö, H. Nurmesniemi, and R. L. Keiski, “Total and size fractionated concentrations of metals in combustion ash from forest residues and peat," Proceedings of the Estonian Academy of Sciences, vol. 58, no. 4, pp. 247-254, 2009.

[27] J. Bower, K. S. Savage, B. Weinman, M. O. Barnett, W. P. Hamilton, and W. F. Harper, "Immobilization of mercury by pyrite $\left(\mathrm{FeS}_{2}\right)$," Environmental Pollution, vol. 156, no. 2, pp. 504514, 2008.

[28] A. K. Müller, K. Westergaard, S. Christensen, and S. J. Sørensen, "The effect of long-term mercury pollution on the soil microbial community," FEMS Microbiology Ecology, vol. 36, no. 1, pp. 1119, 2001.

[29] P. Pant and Ć. M. Allen, "Interaction of soil and mercury as a function of soil organic carbon: some field evidence," Bulletin of Environmental Contamination and Toxicology, vol. 78, no. 6, pp. 539-542, 2007.

[30] F. A. O. Camargo, F. M. Bento, and R. J. S. Jacques, "Uso de microrganismos para remediação de metais," in Tópicos em Ciência do Solo, C. A. Ceretta, L. S. Silva, and J. M. Reichert, Eds., pp. 468-496, Sociedade Brasileira de Ciência do Solo, Minas Gerais, Brazil, 2007.

[31] M. Ravichandran, "Interactions between mercury and dissolved organic matter-a review," Chemosphere, vol. 55, no. 3, pp. 319331, 2004.

[32] A. Kabata-Pendias, Trace Elements in Soils and Plants, CRC Press LLC, Boca Raton, Fla, USA, 3rd edition, 2001.

[33] V. B. Mathema, B. C. Thakuri, and M. Sillanpää, "Bacterial mer operon-mediated detoxification of mercurial compounds: a short review," Archives of Microbiology, vol. 193, no. 12, pp. 837844, 2011. 
[34] K. Möller and T. Müller, "Effects of anaerobic digestion on digestate nutrient availability and crop growth: a review," Engineering in Life Sciences, vol. 12, no. 3, pp. 242-257, 2012.

[35] J. J. Walsh, D. L. Jones, G. Edwards-Jones, and A. P. Williams, "Replacing inorganic fertilizer with anaerobic digestate may maintain agricultural productivity at less environmental cost," Journal of Plant Nutrition and Soil Science, vol. 175, no. 6, pp. 840-845, 2012.

[36] R. B. Frøseth, A. K. Bakken, M. A. Bleken et al., "Effects of green manure herbage management and its digestate from biogas production on barley yield, $\mathrm{N}$ recovery, soil structure and earthworm populations," European Journal of Agronomy, vol. 52, pp. 90-102, 2014.

[37] M. Fernández-Delgado Juarez, S. Waldhuber, A. Knapp, C. Partl, M. Gómez-Brandón, and H. Insam, "Wood ash effects on chemical and microbiological properties of digestate- and manure-amended soils," Biology and Fertility of Soils, vol. 49, no. 5, pp. 575-585, 2013.

[38] A. Demeyer, J. C. Voundi Nkana, and M. G. Verloo, "Characteristics of wood ash and influence on soil properties and nutrient uptake: an overview," Bioresource Technology, vol. 77, no. 3, pp. 287-295, 2001.

[39] R. M. Pitman, "Wood ash use in forestry-a review of the environmental impacts," Forestry, vol. 79, no. 5, pp. 563-588, 2006.

[40] B.-M. Steenari, L. G. Karlsson, and O. Lindqvist, "Evaluation of the leaching characteristics of wood ash and the influence of ash agglomeration," Biomass and Bioenergy, vol. 16, no. 2, pp. 119136, 1999.

[41] J. Száková, P. Ochecová, T. Hanzlíček, I. Perná, and P. Tlustoš, "Variability of total and mobile element contents in ash derived from biomass combustion," Chemical Papers, vol. 67, no. 11, pp. 1376-1385, 2013.

[42] M. J. Sierra, J. Rodríguez-Alonso, and R. Millán, “Impact of the lavender rhizosphere on the mercury uptake in field conditions," Chemosphere, vol. 89, no. 11, pp. 1457-1466, 2012.

[43] A. S. Mehrotra and D. L. Sedlak, "Decrease in net mercury methylation rates following iron amendment to anoxic wetland sediment slurries," Environmental Science and Technology, vol. 39, no. 8, pp. 2564-2570, 2005.

[44] F. E. Rhoton and S. J. Bennett, "Soil and sediment properties affecting the accumulation of mercury in a flood control reservoir," Catena, vol. 79, no. 1, pp. 39-48, 2009.

[45] P. Liang, Y.-C. Li, C. Zhang et al., "Effects of salinity and humic acid on the sorption of $\mathrm{Hg}$ on $\mathrm{Fe}$ and Mn hydroxides," Journal of Hazardous Materials, vol. 244-245, pp. 322-328, 2013.

[46] A. Š́pková, J. Száková, and P. Tlustoš, "Affinity of selected elements to individual fractions of soil organic matter," Water, Air, \& Soil Pollution, vol. 225, no. 1, article 1802, 2014. 

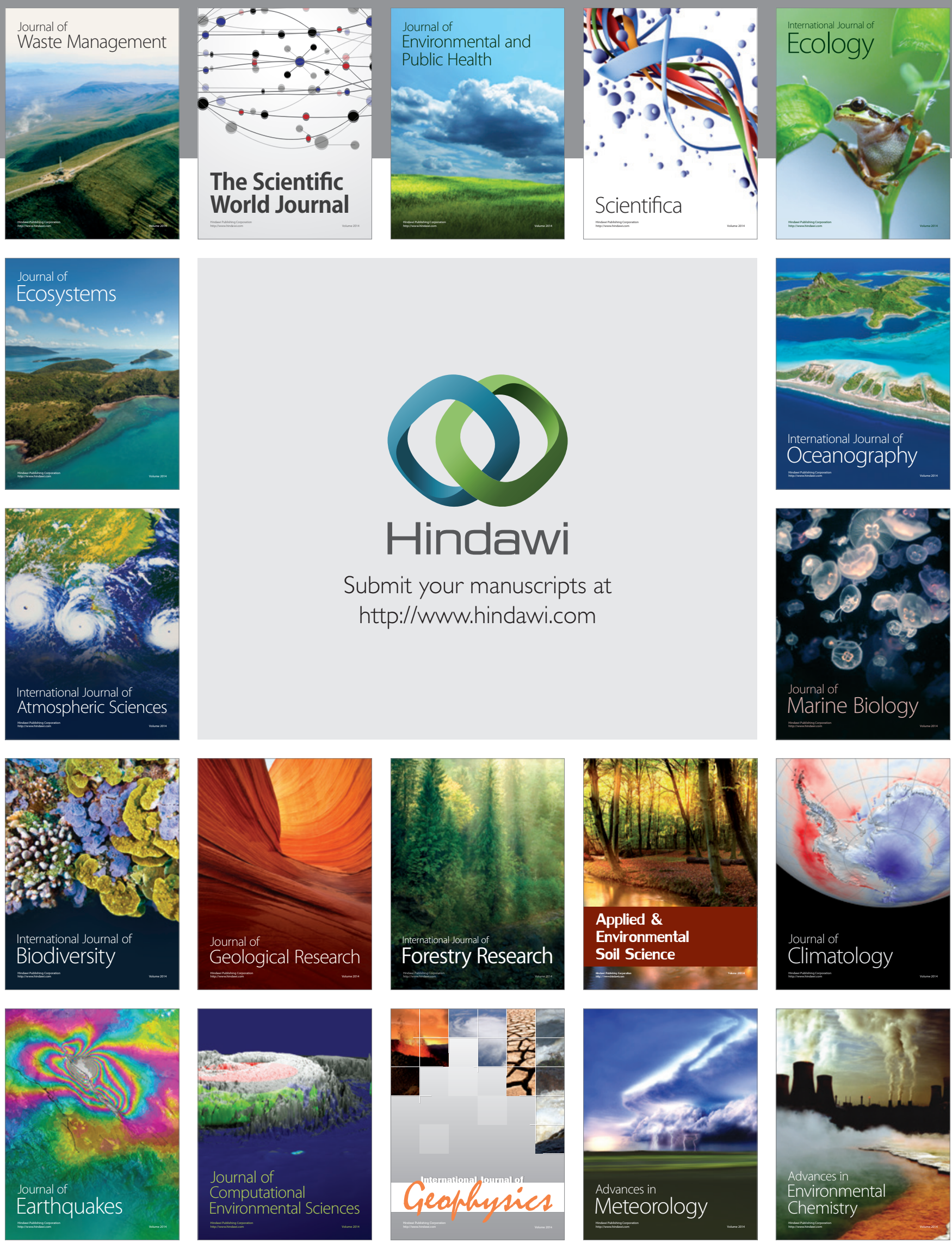